\title{
2 \\ DOENÇAS NEUROLÓGICAS DOS RUMINANTES NO BRASIL: EXAME E DIAGNÓSTICO DIFERENCIAL
}

\author{
NEUROLOGICAL DISEASES OF RUMINANTS IN BRAZIL: \\ EXAMINATION AND DIFFERENTIAL DIAGNOSIS
}

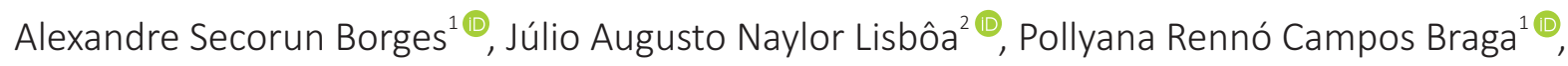 \\ Raissa Oliveira Leite ${ }^{1}{ }^{\circledR}$, Gustavo Rodrigues Queiroz ${ }^{3}$
}

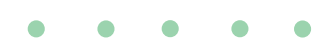

Faculdade de Medicina Veterinária e Zootecnia, Universidade Estadual Paulista (UNESP) Campus de Botucatu, São Paulo, Brasil.

Departamento de Clínica Veterinária, Centro de Ciências Agrárias, Universidade Estadual de Londrina (UEL ), Londrina, Paraná, Brasil.

Faculdade Pitágoras, Universidade Norte do Paraná (UNOPAR), Arapongas, Paraná, Brasil.

Autores para correspondência: alexandre.s.borges@unesp.br janlisboa@uel.br

Revista Brasileira de Buiatria Clínica Médica, Volume 1, Número 3, 2021

ISSN 2763-955X

DOI:10.4322/2763-955X.2021.003

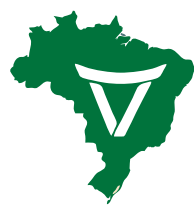

Associação Brasileira de Buiatria

\section{RESUMO}

Os distúrbios do sistema nervoso em ruminantes no Brasil incluem doenças economicamente importantes que apresentam elevada frequência e mortalidade. O sucesso do tratamento e prevenção destas enfermidades depende do diagnóstico. Informações de identificação, anamnese, exame físico e realização do exame neurológico são fundamentais. O exame neurológico deve permitir ao clínico localizar a lesão dentro do sistema nervoso e somado com as informações de identificação e evolução do processo será definida lista de diagnósticos diferenciais. O presente trabalho tem como objetivo apresentar informações relacionadas à prática aplicada destes procedimentos diagnósticos realizados antes da morte. Serão descritas a sequência do exame clínico neurológico, a interpretação dos resultadose a caracterização das síndromes neurológicas. Serão apontadas as doenças neurológicas mais frequentes de ruminantes no Brasil e como é possível, ou não, diferenciá-las com base em critérios clínicos. E, por fim, serão revisados os resultados de exames laboratoriais que reforçam suspeitas ou que confirmam diagnóstico. Estas informações são valiosas ao buiatra que atua no campo, capacitando-o para a formulação de lista de diagnósticos diferenciais mais reduzida e racional. Além disso, podem direcionar decisões terapêuticas coerentes e a orientação de medidas preventivas preliminares sensatas.

Palavras-chave: encefalopatias, exame neurológico, nervos cranianos, neuropatias, sistema nervoso.

\section{ABSTRACT}

This review article aims to describe the neurological exam, the interpretation of results and the characterization of the main ruminant neurological syndromes in Brazil. Such syndromes include economically important diseases that usually present great frequency and mortality. As well, it is important to know the most frequent neurologic diseases and how it is possible, or not, to differentiate them based on clinical criteria. Patient ID, anamnesis, clinical and a discerning neurological exam are essential. In this sense, the lesion within the nervous system can be localized and associated with the previous data, a list of differential diagnoses can be defined. Also, outcomes from complementary exams, such as liquor analysis, antibodies and agent detection, used to confirm the diagnosis is also highlighted. In conclusion, it is endorsed the adoption of a diagnostic methodology, in face of a neurological picture, to the veterinary practitioner under field conditions. In addition, based on the primary diagnosis, coherent therapeutic decisions can be directed, in addition to local or regional preventive measures. 


\section{INTRODUÇÃO}

O clínico buiatra normalmente enfrenta dificuldades para conduzir os casos de doenças neurológicas pelos seguintes motivos: as enfermidades são numerosas, confundem-se entre si porque as manifestações são parecidas e não há sinais patognomônicos, somente excepcionalmente é possível estabelecer o diagnóstico clínico ou terapêutico, o recurso de exames de imagem é limitado, oneroso e restrito a instituições de porte maior, a maioria das doenças provoca a morte sem resposta às tentativas de tratamento, e a confirmação do diagnóstico é estabelecida após a morte e depende da aplicação de rotinas laboratoriais específicas em amostras do tecido nervoso. Na maior parte das vezes, os achados macroscópicos estão ausentes e a necropsia não é esclarecedora, havendo necessidade do exame histopatológico. Todos estes motivos podem servir de desestímulo para o interesse mais aprofundado pelas doenças neurológicas.

A relevância destas enfermidades é, contudo, incontestável. São frequentes, principalmente nos bovinos, e muitas das doenças neurológicas mais importantes podem ocorrer na forma de surtos, causando a morte de número elevado de animais em período curto de tempo. Isto acaba gerando prejuízo econômico significativo para o pecuarista e necessidade de diagnóstico diferencial rápido para que as medidas efetivas de controle, prevenção e, menos frequentemente, terapêuticas possam ser adotadas.

É certo afirmar que a investigação completa e bem-sucedida nestes casos depende do trabalho conjunto de profissionais especializados em diferentes áreas do conhecimento, destacando-se o clínico e o patologista. O clínico, sem o auxílio do patologista, possui possibilidade limitada de concluir o diagnóstico. O patologista, por sua vez, apesar de desempenhar papel decisivo para a definição do diagnóstico, enfrenta o desafio do tempo necessário para o processamento e para o exame das amostras de tecido colhidas. O trabalho em conjunto é vantajoso porque as informações originárias de evidências clínicas bem interpretadas podem direcionar a atenção do exame histopatológico para as áreas de maior interesse, ou seja, aquelas mais provavelmente acometidas no sistema nervoso central (SNC). Resultados mais rápidos e eficientes podem ser esperados deste tipo de interação profissional, o que é positivo e desejável.

O clínico buiatra pode contribuir com informações relevantes desde que seja capacitado para realizar o exame clínico aplicado ao sistema nervoso, interpretar as manifestações e caracterizar a(s) síndrome(s) neurológica(s) presente(s), associando-a $(\mathrm{s})$ com a $\mathrm{a}(\mathrm{s})$ possível(is) localização(ões) da(s) lesão(ões) no SNC. Deve saber quais são as enfermidades mais frequentes que ocorrem na região em que atua e possuir conhecimento suficiente a respeito de seus aspectos epidemiológicos e características clínicas mais prováveis, tais como evolução (início e curso), síndromes neurológicas e desfecho (tempo até a morte). Deve reconhecer as plantas tóxicas com efeitos diretos sobre o SNC, com potencial hepatotóxico e com potencial miotóxico que ocorrem na região em que trabalha. Deve ser capaz de elaborar uma lista racional preliminar de suspeitas e, com base nisto, colher e encaminhar amostras biológicas (líquido cefalorraquidiano - LCR, sangue, soro sanguíneo) para exames laboratoriais específicos. Os resultados destes exames poderão reforçar ou descartar suspeitas e, eventualmente, confirmar diagnósticos mesmo antes da morte.

O presente trabalho tem como objetivo apresentar informações relacionadas à prática aplicada destes procedimentos diagnósticos realizados antes da morte. Serão descritas a sequência do exame clínico neurológico, a interpretação dos resultados e a caracterização das síndromes neurológicas. Serão apontadas as doenças neurológicas mais frequentes de ruminantes no Brasil e como é possível, ou não, diferenciá-las com base em critérios clínicos. E, por fim, serão revisados os resultados de exames laboratoriais que reforçam suspeitas ou que confirmam diagnóstico. Estas informações são valiosas para o buiatra que atua no campo, capacitando-o para a formulação de lista de diagnósticos diferencias mais reduzida e racional. Além disso, podem direcionar decisões terapêuticas coerentes e a orienta- 
ção de medidas preventivas preliminares sensatas.

Ainda que sejam decisivamente importantes para a definição do diagnóstico na maior parte dos casos, os métodos de confirmação após a morte utilizando tecido nervoso, tais como, padrão de lesão histopatológica, métodos especiais de coloração, identificação da presença de antígenos (imunoistoquímica e imunofluorescência direta), do material genético (reação em cadeia da polimerase) e dos próprios agentes envolvidos (cultivos microbiológicos e celulares), estão além do escopo desta revisão. Os leitores poderão, contudo, obter estas informações específicas nos estudos originais referenciados.

Este artigo está subdividido em duas partes principais, na primeira delas apresentaremos o exame neurológico, onde os conceitos são revisados, apresentando a experiência dos autores e em seguida algumas referências específicas são sugeridas para complementar a leitura. $\mathrm{Na}$ segunda etapa apresentamos dados sobre as principais enfermidades neurológicas no $\mathrm{Bra}-$ sil, seguindo o modo usual de apresentação da informação seguida pelo autor da citação.

\section{EXAME NEUROLÓGICO}

\section{- Conceitos iniciais do exame neurológico}

Em um primeiro momento, devemos relembrar que o exame neurológico faz parte do exame clínico. Para que seja possível realizar o tratamento ou a profilaxia das enfermidades é necessário que haja o diagnóstico, portanto, o objetivo do exame neurológico é fornecer informações ao clínico para que seja possível o estabelecimento de uma lista de diagnósticos diferenciais. Usando esta lista é possível escolher adequadamente os exames complementares a serem realizados para refiná-la, conforme a disponibilidade, viabilidade técnica e econômica dos mesmos. Portanto, sem o exame neurológico não teremos uma lista de diagnósticos diferenciais ante mortem adequada ou, a mesma será tão longa que não conseguiremos estabelecer os exames complementares que possam cobrir as principais suspeitas.

\section{- O exame neurológico deve responder duas perguntas inicialmente:}

(1) Os sinais clínicos observados são decorrentes de uma anormalidade neurológica?

Esta parece ser uma pergunta simples, mas muitas vezes não é. Ao realizar o exame neurológico, usualmente já realizamos um exame físico geral e a avaliação de outros sistemas. Esta avaliação é muito importante pois às vezes um animal desidratado apresenta-se apático a ponto de deixar o clínico em dúvida se a diminuição do nível de consciência é decorrente de uma anormalidade no sistema nervoso. $\mathrm{O}$ mesmo pode ocorrer durante a hipóxia cerebral após um quadro grave de anemia ou, em um paciente que esteja em decúbito por apresentar uma lesão osteomuscular. $\mathrm{O}$ exame clínico permite a exclusão de anormalidades em outros sistemas que provoquem sinais como apatia, decúbito, etc. Imagine também um paciente com lesão hepática grave, o mesmo pode apresentar um quadro de encefalopatia hepática, porém usualmente, apresenta outros sinais durante a obtenção de seu histórico e exame clínico, como por exemplo, icterícia, lesões de fotossensibilização ou alterações no tamanho do fígado. Portanto, o exame de todos os sistemas adiciona informações importantes para este paciente.

2 Onde está localizada a lesão dentro do sistema nervoso?

Quando o examinador responde sim à primeira pergunta, o próximo passo é localizar a lesão dentro do sistema nervoso. Esta etapa descreveremos com mais detalhes nos próximos parágrafos. Porém, precisamos compreender o porquê localizar a lesão no sistema nervoso é tão importante. Não importa a espécie ou a raça do animal afetado, lesões em determinadas áreas do sistema nervoso provocarão sinais clássicos. Por exemplo, não importa se é um ovino com dez dias de vida ou uma búfala de dez anos, se ambos apresentarem sinais cerebelares eles serão muito similares entre os dois pacientes (hipermetria, tremores de cabeça, perda de equilíbrio). Localizar a lesão no sistema nervoso central 
tem influência prática e clara em dois pontos imediatos:

10) determinadas enfermidades acometem áreas específicas com muito mais frequência que outras. Por exemplo, a listeriose usualmente acomete o tronco encefálico afetando diferentes pares de nervos cranianos, enquanto a polioencefalomalácia, por deficiência no metabolismo da tiamina, provocará lesões cerebrais características.

2o) localizar a lesão a partir dos sinais clínicos observados também significa maior probabilidade de amostragem de regiões com lesões durante a necropsia de um paciente. Portanto, saber que a lesão era na cauda equina ou na medula cervical, muda completamente a abordagem da colheita e aumentam as chances de obtenção de fragmentos da região correta, permitindo ao patologista ter em mãos material que lhe permita chegar ao diagnóstico.

Antes de planejar o exame, o clínico deve levar em consideração os seguintes aspectos:

Identificação do paciente: saber a espécie, idade, raça, sexo são aspectos fundamentais. Existem muitas enfermidades comuns a diferentes espécies, porém, há enfermidades que são espécie-específicas ou que ocorrem com maior frequência em uma determinada espécie. Exemplos claros são a leucoencefalomalacia dos equí- deos, devido a ingestão de fumonisina B1, mas que não afeta o sistema nervoso de ruminantes, por outro lado sabemos que determinadas enfermidades são mais comuns em algumas idades, como por exemplo a babesiose cerebral, muito mais frequente em bezerros jovens do que em animais adultos.

Evolução do processo: esta informação é obtida junto a anamnese e traz informações muito importantes sobre a progressão do caso clínico neurológico. Enfermidades traumáticas apresentam início súbito e os sinais clínicos mais relevantes dentro das primeiras 24 horas evoluindo para estabilização ou melhora lenta (logicamente casos de óbito podem ocorrer quando as lesões são graves). Por outro lado, enfermidades degenerativas terão uma evolução muito mais lenta, chegando algumas vezes a meses de evolução, enquanto casos de enfermidades infecciosas possuirão evolução de dias.

Portanto, o clínico deve ter em mente que quando a resposta for sim à primeira pergunta e após excluir lesões em outros sistemas como causa dos sinais observados, ele deverá associar a identificação do paciente, a evolução da enfermidade e o local da lesão determinado durante o exame. Estas três informações constituem-se na base da orientação do exame neurológico e

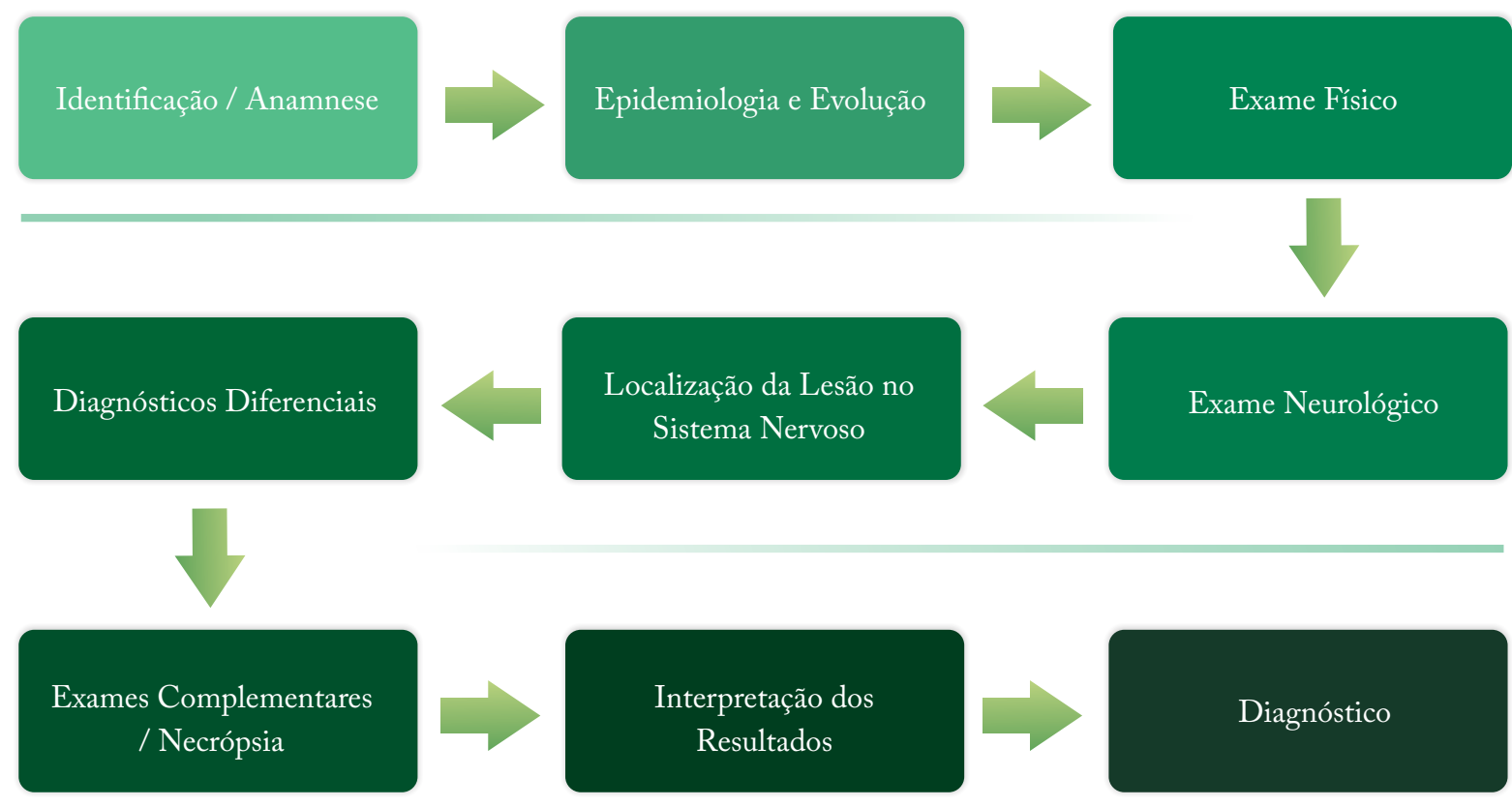

Figura 1.Etapas do exame neurológico para o diagnóstico das neuropatias em ruminantes. 
somadas à anamnese permitirão montar uma adequada lista de diagnósticos diferenciais que direcionarão a escolha dos exames complementares. A lista de diagnósticos diferenciais deve ser a mais ampla contemplando todas as enfermidades possíveis, porém também deverá ser a mais específica possível para não dificultar a escolha dos diferentes diagnósticos diferenciais. Esta lista também direciona a colheita e amostragem post mortem quando o paciente vier naturalmente a óbito ou for sacrificado (Figura 1).

Neste momento, temos de ressaltar o quanto a anamnese é importante. Costumamos dizer que uma anamnese bem conduzida resulta em mais de $70 \%$ de chances de chegar a um diagnóstico correto. $\mathrm{O}$ conhecimento das diferentes enfermidades que acometem o sistema nervoso melhora a anamnese, através da realização de perguntas mais objetivas e relevantes ao processo. Saber quais as enfermidades mais importantes em sua região geográfica, também é fundamental. Saber quantos animais adoeceram, e quantos se recuperaram, como os sinais clínicos iniciaram e qual o tempo de evolução, saber se algum tratamento foi efetivo, qual a alimentação recebida e se existe alguma particularidade nesta alimentação entre lotes de animais afetados e não afetados, ou mesmo a ocorrência de animais afetados em apenas um ou mais piquetes da propriedade pode fazer toda diferença. Recentemente, verificamos o aumento de casos de raiva em bezerros ao redor de dois meses de idade, sem que animais adultos apresentassem problemas, mas ao abordar a anamnese verificamos que as vacas só foram vacinadas um mês após o parto. Outras vezes, o excesso de enxofre presente na dieta de um lote de garrotes em sistema de semiconfinamento ocasionou a polioencefalomalacia.

Ao montar a lista de diagnósticos diferenciais devemos colocar os mais prováveis no início da lista e, em seguida, os demais. Devemos sempre lembrar que apresentações incomuns de enfermidades frequentemente diagnosticadas são mais prováveis que apresentações usuais de enfermidades de ocorrência rara. A raiva continua sendo a enfermidade neurológica mais importante em ruminantes no Brasil e, portanto, deve ser incluída na lista de diagnósticos diferenciais em todos os pacientes com sinais neurológicos, o examinador deve usar equipamento de proteção (especialmente luvas), estar vacinado e conhecendo seu título de anticorpos através de exame realizado dentro dos últimos doze meses.

Apresentaremos a seguir uma abordagem simples da neuroanatomia e conceitos relevantes para realização do exame neurológico.

\section{- Principais divisões anatômicas e definições úteis para o exame}

A suspeita de que os sinais clínicos anormais apresentados pelo paciente sejam decorrentes de uma anormalidade no sistema nervoso necessitará que o examinador realize o exame neurológico. Após este exame ele deverá localizar, de modo mais específico possível, onde está a lesão.

\section{Quais seriam as possíveis localizaçôes?}

De modo geral, subdividimos o sistema nervoso em: sistema nervoso central (SNC) e sistema nervoso periférico (SNP). O SNC é composto pelo encéfalo (todas estruturas contidas dentro da calota craniana acima do forame magno) e a medula espinhal. O SNP corresponde aos axônios dos nervos espinhais e cranianos, gânglios (conjuntos de corpos celulares localizados fora do SNC e que desempenham a mesma função) e mais receptores e partes do sistema nervoso autônomo.

Muitas vezes após o exame neurológico realizado em um animal a campo, será possível apenas saber se o paciente possui uma anormalidade neurológica e, se a mesma está localizada no encéfalo, na medula espinhal ou mesmo no sistema nervoso periférico, outras vezes o exame neurológico permitirá uma localização mais específica (Figura 2).

O encéfalo pode ser subdividido em cérebro (conjunto de telencéfalo e diencéfalo), tronco encefálico (mesencéfalo, ponte e bulbo) e cerebelo (Figura 3).

Observe que encéfalo e cérebro não são sinônimos e devem ser usados em sua definição correta para indicar de modo preciso a localização da lesão. Lembre-se que existem enfermidades que acarretam lesões 


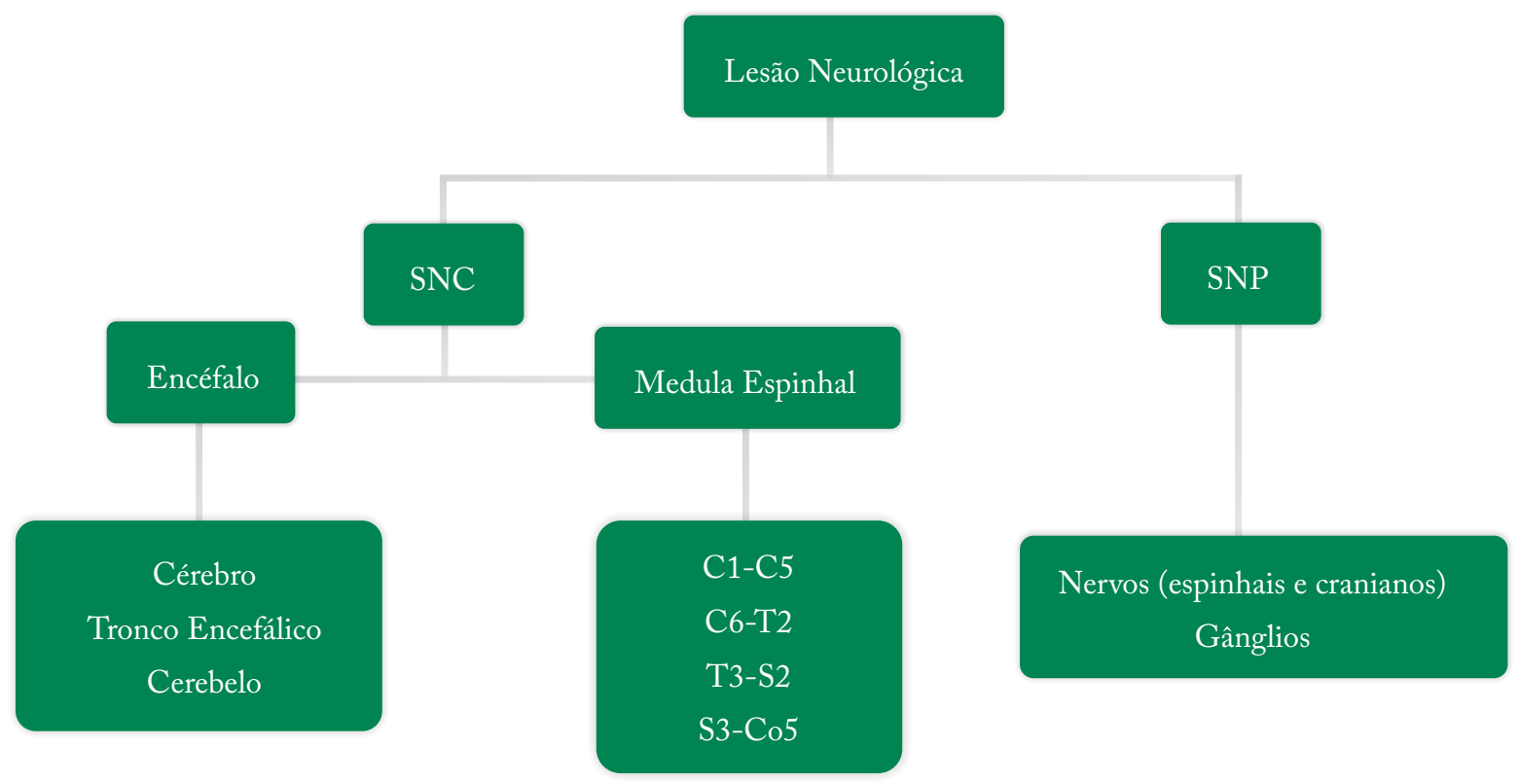

Figura 2.Localização das anormalidades no sistema nervoso.

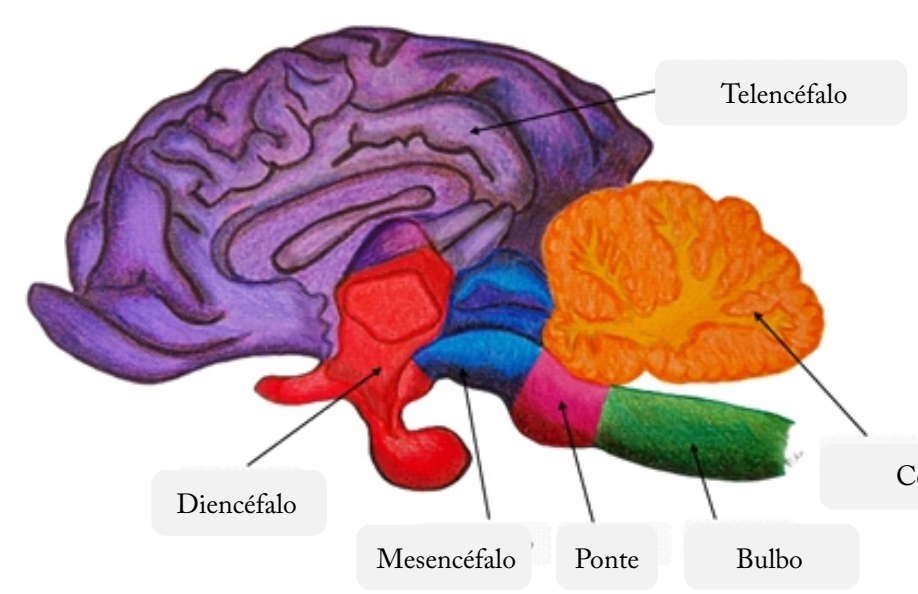

em áreas preferenciais e quando esta área é afetada, acarretará um conjunto de sinais ou sintomas definidos com síndrome, que o examinador identificará com facilidade. Estes sinais serão descritos na próxima etapa do exame. Ressaltamos que, frequentemente, pacientes apresentam lesões multifocais ou difusas o que dificulta localização da lesão a uma área única. O tronco encefálico controla inúmeras funções relacionadas às funções vitais, como por exemplo, respiração, vigília e sono, além de possuir os núcleos (conjunto de corpos celulares de neurônios que controlam as mesmas funções e estão localizados dentro do SNC) de dez pares de nervos cranianos. Apenas o I e II pares de nervos cranianos não possuem núcleo no tronco encefálico (Figura 4).
Figura 3. Representação esquemática e divisões de encéfalo bovino, composto por telencéfalo, diencéfalo, mesencéfalo, ponte, bulbo e cerebelo. Cérebro $=$ telencéfalo + diencéfalo . Tronco encefálico: mesencéfalo + ponte + bulbo. Cada uma dessas áreas quando afetadas podem provocar síndromes específicas.

Cerebelo

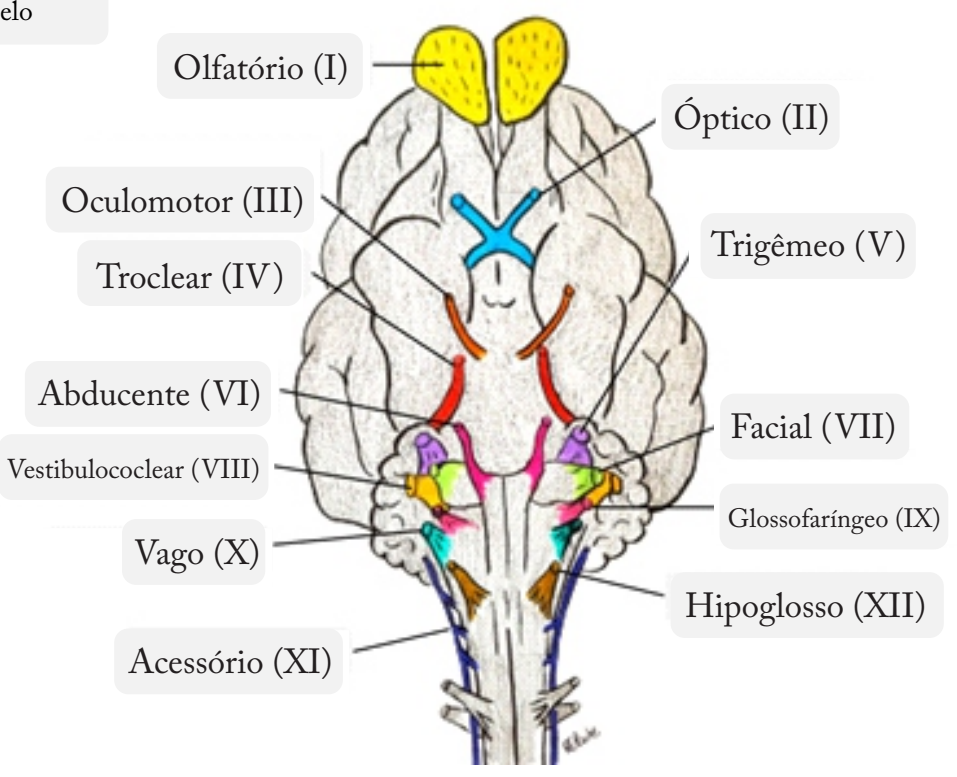

Figura 4. Nervos cranianos e sua posição no encéfalo. Vista ventral de encéfalo representando a localização dos doze pares de nervos cranianos. Observe que dez dos doze pares apresentam seu núcleo no tronco encefálico. Sendo assim, lesões em tronco encefálico podem acarretar paralisia de vários pares de nervos. 
A medula espinhal possui cinco áreas que permitem uma localização mais específica, principalmente em pacientes mais leves. Bezerros, ovinos, caprinos podem ser submetidos a manobras especiais durante o exame neurológico as quais fornecem informações adicionais. Estas cinco áreas são: região medular cervical (segmento $\mathrm{C} 1-\mathrm{C} 5$ ), região medular cérvico-torácico (segmento medular C6-T2), segmento medular torácico (T3-L3), segmento medular tóraco-lombar (L4-S2) e segmento sacrococcígeo (S3 final cone medular) (Figura 5).

Segmento medular é uma porção medular específica de onde emerge um par de nervos espinhais e não corresponde em todos os locais aos corpos vertebrais de mesmo número. Existe uma proporção entre número de vértebras e segmentos medulares, por exemplo os ruminantes possuem treze vértebras torácicas e, portanto, possuem treze segmentos medulares. A exceção é a região cervical que possui oito segmentos medulares e sete vértebras. De modo geral, existe uma boa correlação anatômica entre segmento medular e vértebras, mas a partir do final da região torácica e início da região lombar, os segmentos medulares são progressivamente menores que o tamanho vertebral e isto acarreta o término da medula vertebral na altura da segunda vértebra lombar em ruminantes. A partir desta região tem início a cauda equina, que nada mais é do que o conjunto de nervos espinhais que permanecem dentro do canal medular até encontrarem o seu forame vertebral correspondente (sim, cada segmento medular emite um par de nervos espinhais que deixará o canal medular na vértebra correspondente). Estes nervos do conjunto da cauda equina realizam a inervação da cauda, ânus, bexiga e captam a sensibilidade da região perineal.

A medula espinhal possui uma estrutura muito organizada onde tratos e fascículos motores e sensoriais levarão, respectivamente, informações motoras para a

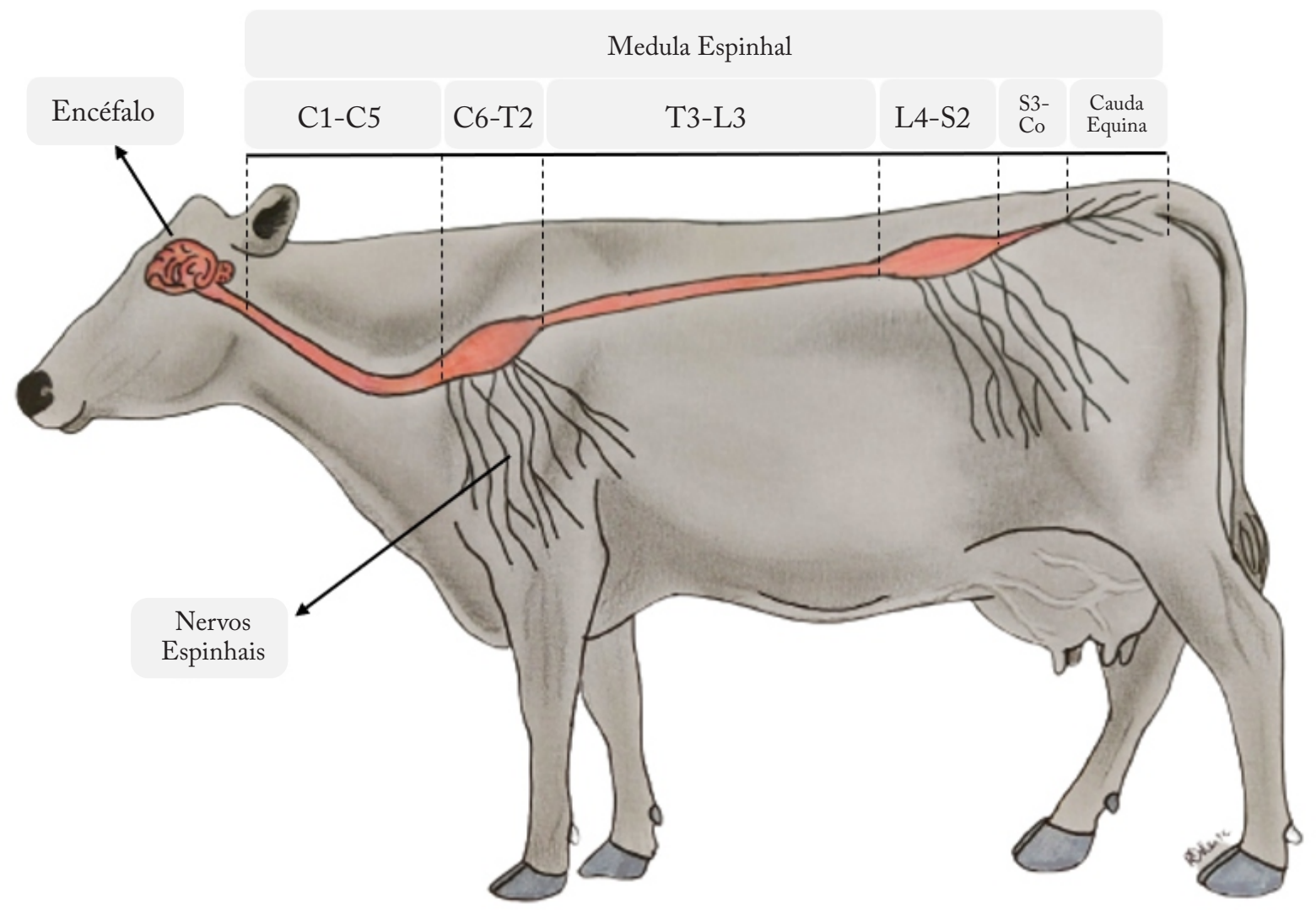

Figura 5. Sistema nervoso central: composto pelo encéfalo e medula espinhal. Regiões funcionais da medula espinhal: C1-C5, C6T2 (intumescência braquial), T3-L3, L4-S2 (intumescência lombo-sacra), Cauda equina. Sistema nervoso periférico: nervos espinhais. 
periferia (neurônios motores eferentes) ou captarão informações no sistema nervoso periférico e conduzirão até o encéfalo (neurônios sensoriais aferentes). A medula espinhal possui a substância cinzenta ( $\mathrm{H}$ medular) composta por corpos celulares e a substância branca composta predominantemente por axônios dos neurônios. Maiores detalhes sobre as diferentes regiões da medula espinhal e sua relação com os sinais clínicos serão apresentados a seguir durante a explanação sobre o exame neurológico.

Logicamente a anatomia do SNP e SNC contém muito mais detalhes dos que os apresentados até o momento, mas esta abordagem simples é a base para ser utilizada durante o exame neurológico a campo.

\section{- Como examinar o paciente com anormalidade neurológica?}

Temos de nos conscientizar que a realização do exame do sistema nervoso é uma tarefa simples, especialmente quando seguimos um roteiro de avaliação. Ressaltamos que, usualmente, quando olhamos o paciente com anormalidade neurológica, a primeira pergunta que fazemos é: qual é o diagnóstico?

Chegar ao diagnóstico é fundamental, como comentamos anteriormente, mas esta busca sem metodologia pode ofuscar o resultado final. Portanto, a sequência de raciocínio deve ser: identificar o paciente, obter uma anamnese (incluindo dados de rebanho), realizar o exame neurológico e dos outros sistemas, identificar anormalidades e interpretá-las para, assim, podermos inferir que as anormalidades observadas são decorrentes de alterações do sistema nervoso e localizar a lesão. E aí surge a primeira dúvida: Como podemos realizar o exame de um sistema que não palpamos, não auscultamos, não percutimos e com poucas exceçôes não vemos (papila óptica)? A resposta é simples, examinamos utilizando dois métodos:

A Avaliamos as funções e anotamos se algo não está com seu funcionamento adequado.
B Realizamos testes e observamos as respostas aos mesmos (reflexos e respostas aos estímulos) e interpretamos como normal ou anormal.

Quando seguimos estas duas etapas, automaticamente nos conscientizamos que realizamos exame neurológico todos os dias em todos os pacientes. Ao palpar uma vaca e observarmos o tônus de cauda e tônus anal, estamos realizando exame neurológico, ao observarmos um bovino apreendendo alimentos, mastigando e deglutindo, estamos realizando exame neurológico, ao observarmos um bovino a campo locomovendo de modo correto e notando a chegada de uma pessoa próxima (vendo, ouvindo) estamos verificando comportamentos mantidos pelo sistema nervoso, ao observar um ovino se locomovendo adequadamente em direção à comida o mesmo depende do sistema nervoso para realizar estas funções. Muitos outros exemplos seriam possíveis, pois toda a integridade destas funções depende da normalidade do sistema nervoso e, rapidamente, você observará caso estes pontos estejam anormais. Cada examinador é, todos os dias, um neurologista a partir do momento em que analisa as funções corretas desempenhadas por cada animal, mesmo sem se lembrar destes pontos. O método agora é observar, interpretar e associar a disfunção a uma localização do sistema nervoso.

Como mencionado há pouco, às vezes apenas a observação não é suficiente e precisamos realizar testes e induzir respostas ou reflexos para entendermos o que ocorrerá e assim interpretarmos pontos importantes durante o exame neurológico. Sendo assim, fazemos um gesto de ameaça em direção ao olho para obtermos uma resposta de fechamento palpebral e/ou movimento de cabeça, submetemos luz em direção ao olho para obter um reflexo pupilar ou realizamos o reflexo patelar.

Ressaltamos que o neurônio é a célula mais importante para realização do exame neurológico e a interação entre neurônios motores e sensoriais constitui a base para interpretação dos achados (Figura 6).

Desta forma, exemplificaremos a seguir a condução do exame do encéfalo e medula espinhal. Posteriormente, definiremos as principais síndromes que 


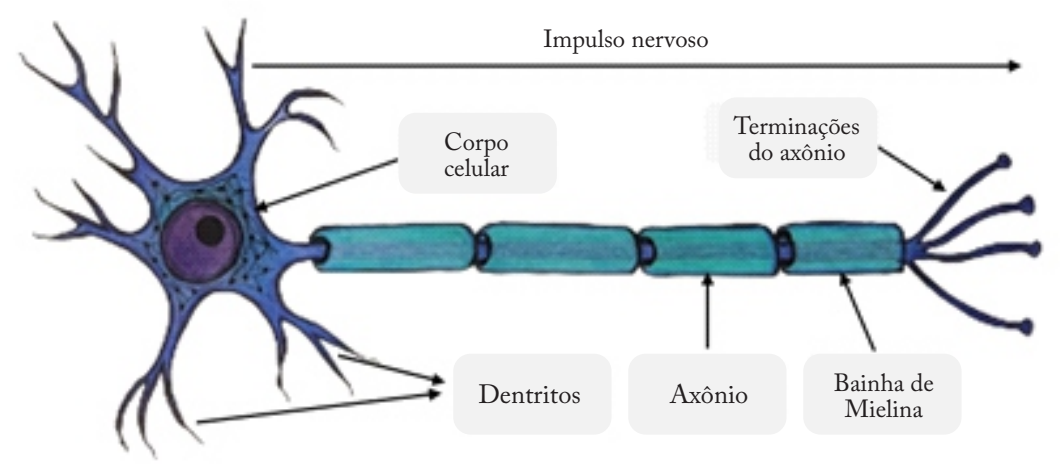

Figura 6. Estrutura do neurônio motor. Neurônios são as células mais importantes para o exame neurológico, uma vez que são excitáveis, ou seja, que conseguem responder aos estímlos provocados com modificações da diferença de potencial elétrico na membrana celular, permitindo que o exame neurológico seja realizado. A modificação desse potencial pode propagar-se pela membrana, fenômeno conhecido como impulso nervoso. É por meio do impulso nervoso que os neurônios conseguem transmitir informações de um neurônio para outro ou para glândulas ou músculos. Assim sendo, o neurônio atua garantindo a recepção e transmissão de informações.

permitirão, junto aos dados de anamnese, identificação do paciente e evolução clínica, estabelecer as principais suspeitas clínicas (lista de diagnósticos diferenciais).

\section{- Como realizar e interpretar o exame do encéfalo}

Devemos lembrar que as estruturas encefálicas determinam o comportamento, nível de consciência, posição e movimentação da cabeça e a função dos nervos cranianos (lembrar sempre que podem ocorrer lesões periféricas nos nervos cranianos no trajeto de seu axônio e serão posteriormente mencionadas). Portanto, lesões encefálicas devem ocasionar uma ou mais anormalidades nas funções acima citadas.

Avaliar o encéfalo significa saber se o comportamento apresentado por aquele paciente é o adequado para a espécie, idade e raça, algumas vezes informações anteriores com tratadores de animais manejados de forma mais intensiva podem complementar este tipo de avaliação. Comportamentos anormais podem ser exemplificados por agressividade, andar compulsivo, emissão de sons, procura por objetos inanimados, pressão da cabeça contra obstáculos. Lesões cerebrais (telencefálicas ou diencefálicas) usualmente provocam anormalidades de comportamento. O nível de consciência pode estar abaixo ou acima do normal. É possí- vel avaliar um paciente que está com nível de consciência abaixo do normal (obnubilado), semicomatoso, comatoso ou, eventualmente, um paciente com um quadro excitatório como o causado por enfermidades tóxicas, que podem deixá-lo mais reativo e com maior excitabilidade.

Devemos observar que apatia nem sempre está relacionada a uma anormalidade neurológica. Enfermidades que causem dor, assim como quadros de desidratação, anemia, toxemia e anormalidades em outros sistemas podem alterar a função do sistema nervoso. Sendo assim, estas enfermidades podem ser previamente descartadas durante o exame clínico e devem ser corrigidas para verificação do nível de consciência posteriormente. Vale ressaltar que quadros convulsivos são sempre decorrentes de anormalidades cerebrais (usualmente telencefálicas) e indicam uma anormalidade também no encéfalo.

A próxima etapa é verificar se o paciente apresenta anormalidades no posicionamento de cabeça ou pescoço como por exemplo: o opistótono (pode ser causado por lesões cerebrais ou mesmo cerebelares), tremores de cabeça (lesões cerebelares) ou rotação da cabeça (head tilt) que pode ser um sinal de síndromes vestibulares centrais (rotação de cabeça pode também ser periférica e será exemplificado posteriormente).

$\mathrm{O}$ exame pode seguir pela avaliação dos nervos 
cranianos. O examinador menos habituado com avaliação neurológica geralmente apresenta uma maior dificuldade nesse momento. Este fato está baseado na dificuldade de perceber como é simples uma avaliação inicial (este é nosso objetivo no texto atual), que pode é logico, se transformar em algo mais detalhado para um neurologista que procura uma localização mais específica da lesão, o que geralmente não é necessário para o exame neurológico realizado a campo.

Ao avaliar os nervos cranianos devemos lembrar que cada um deles pode ser sensorial (conduz informações sensoriais para serem processadas no encéfalo), motor (conduz informações motoras geradas no núcleo para um músculo) ou mistos (contém fibras motoras e sensoriais). De modo geral, os nervos cranianos levam informações que permitem aos músculos movimentar voluntariamente os lábios, as pálpebras, a língua, ou, eventualmente, de forma involuntária as cartilagens da laringe e a musculatura envolvida na deglutição. Os nervos cranianos permitem também transportar informações sensoriais como visão, audição, fibras sensoriais da língua, sensibilidade da face, etc.

Para o exame dos nervos cranianos devemos conhecer as funções desempenhadas por cada par de nervo craniano e observar se estão normais ou anormais, ou podemos agrupar regiões da face e depois correlacionar com a função dos nervos cranianos. Independente da metodologia, o resultado será o mesmo: observar se há uma perda da função e correlacionar com o nervo craniano afetado.

Lesões encefálicas afetam o núcleo do nervo craniano. Lesões mais extensas no tronco encefálico podem acarretar lesões em mais de um núcleo de nervo craniano, dependendo da sua proximidade e extensão. Lembre-se que algumas vezes uma lesão em um nervo craniano não significa especificamente que a lesão é no encéfalo, pois alguns deles, particularmente o nervo facial, tem seus axônios (SNP) localizados de forma mais superficial após a saída do crânio e estão sujeitos a lesões (no caso de otites o nervo vestibulococlear) ou traumas na face (nervo facial) ocasionando anormalidades. Os quadros 1, 2 e 3 demonstram onde está o núcleo de cada nervo craniano, qual a função de cada um deles, o teste a ser realizado e qual o conjunto de nervos cranianos responsável por algumas funções. Lembrando que outras particularidades existem, mas não são fundamentais para localizar as lesões nas fases iniciais.

- Primeiro par de nervo craniano (olfatório, NC I): não nos oferece informações úteis no exame, pois muitas vezes animais apáticos não demonstraram interesse por alimentos com odor e não conseguimos informações importantes sobre o processo neurológico.

- Nervo craniano óptico (NC II): é muito importante de ser avaliado e aqui valem algumas considerações iniciais que complementam as informações apresentadas nas tabelas. Usualmente, começamos a avaliação deste nervo observando se o paciente consegue se locomover em um ambiente sem tocar obstáculos de diferentes tamanhos, em seguida, avaliamos a ameaça visual e veremos se ele fecha a pálpebra. A ameaça visual é uma manobra onde um gesto ameaçador é realizado em direção ao olho, sem tocar a pálpebra ou cílios e sem deslocamento excessivo de ar. O nome desta prova é ameaça visual e não reflexo pois a reposta obtida não é involuntária, ela é mediada por outras regiões do encéfalo que possuem uma maior integração. A resposta visual correta é o fechamento da pálpebra e, em alguns pacientes, a retirada concomitante da cabeça. Para que esta resposta seja obtida, deve existir normalidade de todas as vias que levam a informação até ser decodificada na região do córtex occipital. Estas vias são compostas pelo nervo óptico que chega até o quiasma óptico e as fibras decussam (termo utilizado para descrever a troca de lado dentro do SNC). Aproximadamente 90\% das fibras contendo informação visual captada no olho direito agora vão para o lado esquerdo do encéfalo e vice-versa. Em seguida, a informação é transmitida pelos tratos ópticos até as radiações ópticas e córtex occipital. Portanto, 90\% da informação visual captada no olho direito será processada no córtex occipital esquerdo e vice-versa. O mesmo vale para lesões do lado esquerdo do córtex occipital que afetarão, principalmente, as respostas de ameaça visual contralateral. Alguns pacientes podem ter lesões (abscessos são 
comuns) na região de quiasma óptico e a perda visual ser bilateral. Pacientes que não enxergam e não possuem uma adequada resposta à ameaça visual devem ser submetidos a uma avaliação ocular para determinação da existência de anormalidades no globo ocular que sejam responsáveis por alterações na passagem da informação visual.

Em seguida procure também realizar o reflexo pupilar, este sim um reflexo clássico (resposta involuntária a um determinado estímulo, sendo que para ser efetuado necessita de neurônios sensoriais que captam a informação e que se conectam diretamente, ou com o auxílio de um interneurônio, a um neurônio motor que efetuará a resposta). O reflexo pupilar complementa de forma muito significativa a interpretação da localização da lesão em um paciente cego. O reflexo pupilar, de uma forma simplificada, é o fechamento da pupila após o estímulo luminoso. Portanto, o neurônio sensorial que leva a informação está contido no nervo óptico e o neurônio motor que efetua o fechamento da pupila é o neurônio motor contido dentro do nervo oculomotor. Esta conexão com o nervo oculomotor se dá no núcleo do oculomotor (onde estão localizados os corpos celulares) no mesencéfalo, que ao serem estimulados levam a informação para a musculatura responsável pelo fecha- mento da pupila. Este reflexo protege a retina de uma exposição muito intensa à luz solar (Figura 7).

Associar a capacidade visual e o reflexo pupilar ajudam muito o examinador durante seu exame. Vamos analisar dois diagnósticos diferenciais completamente diferentes que podem exemplificar a importância destes procedimentos. Um paciente cego sem reflexo pupilar tem uma lesão anterior ao núcleo do nervo oculomotor, geralmente nos nervos ópticos até o quiasma óptico. Lesões bilaterais no nervo óptico ou uma lesão no quiasma óptico impedirão a chegada de informação visual até o córtex occipital e, portanto, ele estará cego; porém ao mesmo tempo uma lesão nestas áreas impedirá a chegada da informação até o mesencéfalo e, consequentemente, o núcleo do oculomotor não será estimulado e o paciente terá a pupila dilatada (midríase permanente). Portanto, nestas lesões você terá um paciente cego e em midríase não responsiva (termo utilizado para descrever a pupila dilatada não responsiva ao estímulo luminoso). Um exemplo claro é a intoxicação por closantel em pequenos ruminantes. Este produto, muito útil para o controle de parasitas gastrointestinais, pode causar (quando administrado em doses acima do índice de segurança) lesão significativa nos nervos ópticos. Os animais estarão cegos e com a pupila dilata-

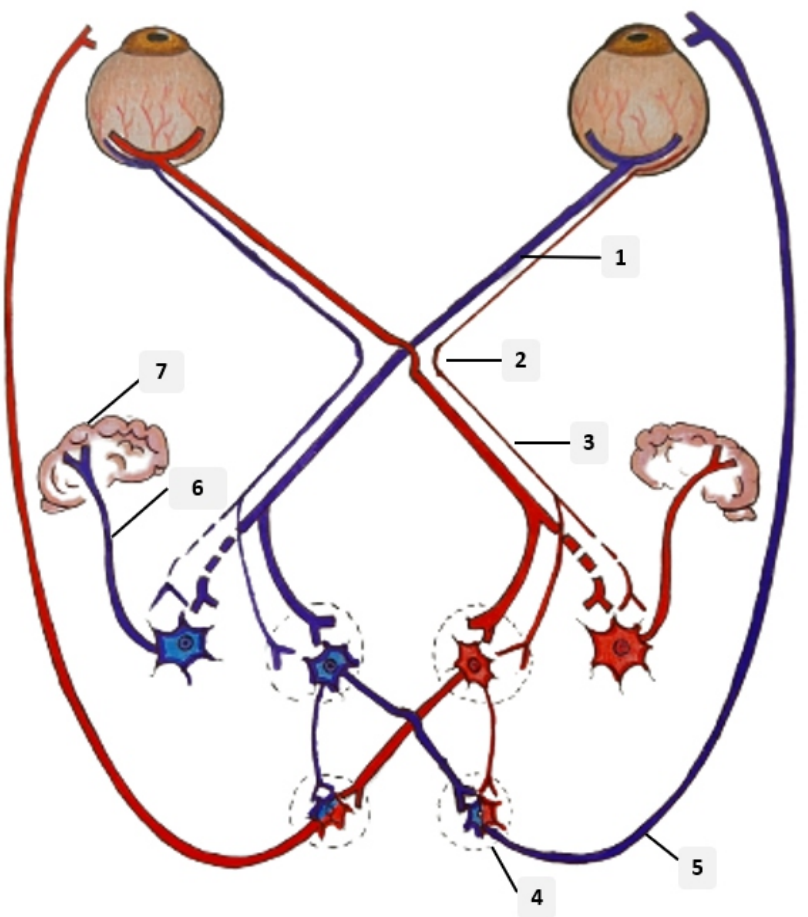

Figura 7. Vias visuais e reflexo pupilar. Representação esquemática do arco reflexo motor: esta via permite a visão ligada ao $\mathrm{NC}$ II assim como o reflexo pupilar via NC III. A maior parte das informações captadas pelo olho direito serão decodificadas no córtex occipital esquerdo, portanto caracteriza-se em uma visão contralateral. A luz estimulará o nervo óptico ipsilateral e provocará o reflexo pupilar via NC III. No quiasma óptico $90 \%$ das fibras cruzam de lado e somente $10 \%$ permanecem ipsilaterais. 1. Nervo óptico direito, 2. Quiasma óptico, 3. Trato óptico, 4. Núcleo do nervo oculomotor, 5. Nervo oculomotor, 6. Radiação óptica e 7. Córtex occipital. 


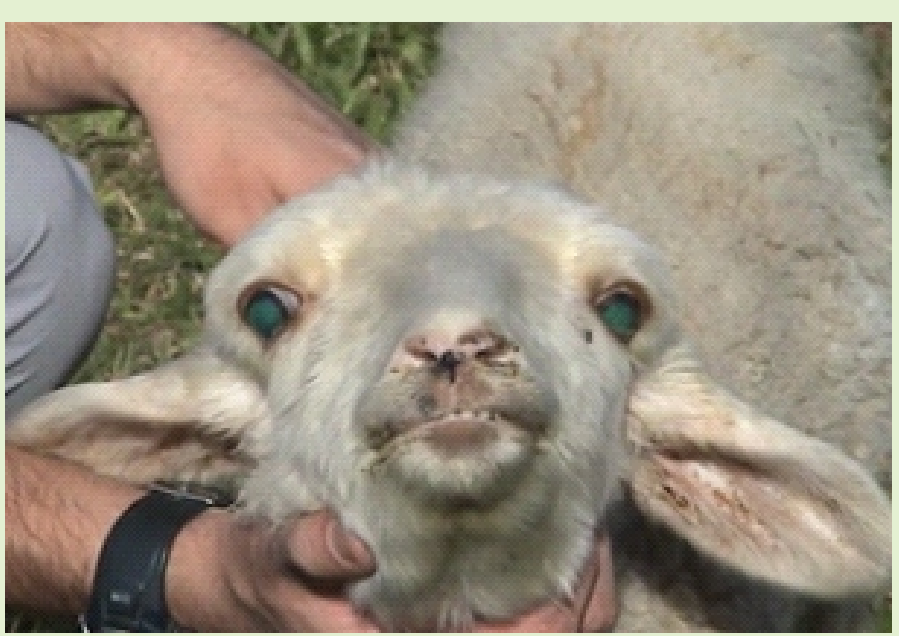

Figura 8. Ovino apresentando dilatação pupilar bilateral devido à lesão bilateral do nervo óptico após sobredosagem de closantel.

\section{da (Figura 8).}

Situação completamente diferente ocorre em pacientes com polioencefalomalácia, causada por deficiência no metabolismo da tiamina (vitamina B1), que apresentam predominantemente, uma lesão cortical occipital, local onde o estímulo luminoso é interpretado, mas posterior à área de mesencéfalo (núcleo do III par de NC). Este paciente estará cego, mas terá reflexo pupilar normal. Esta cegueira com reflexo pupilar normal é denominada de amaurose ou cegueira central. Portanto, ao se constatar que o paciente está cego a próxima etapa é verificar se ele possui reflexo pupilar e se suas pupilas estão dilatadas ou no tamanho normal. Para realização do reflexo pupilar, não é necessário ter o paciente em uma sala escura, basta apenas fechar os dois olhos do animal com as mãos por trinta segundos. Se estiver em um ambiente com elevada luminosidade, abre-se um dos olhos para verificar se a pupila fecha; ou se estiver em um período com pouca luz, pode utilizar uma fonte de luz artificial e verificar a resposta. Lembramos que com paciente na luz do dia, não basta fechar apenas um olho e testar o reflexo pupilar, os dois olhos têm que ser fechados simultaneamente e depois um deles aberto, caso contrário, o que ficou aberto provocará reflexo pupilar indireto no outro e atrapalhará seu exame. O nervo oculomotor também é responsável por levar informações motoras à musculatura responsável por deslocar o globo ocular medialmente e lesões neste nervo acarretarão estrabismo lateral.

Os outros pares de nervos cranianos seguem uma avaliação muito mais simples:

- Quarto par de nervo craniano (IV troclear): responsável pela rotação do globo ocular dentro da órbita.

- Quinto par de nervo craniano ( $\mathrm{V}$ trigêmeo): inerva o masseter, músculo que contribui com a movimentação da mandíbula durante a mastigação, e por ser um nervo misto, também é responsável pela sensibilidade facial através dos seus diferentes ramos. Uma lesão na porção motora do núcleo do $\mathrm{V}$ par causará uma atrofia muscular facilmente observada na região de masseter, que por ser uma atrofia neurogênica, se estabelece rapidamente. Os diferentes ramos do $\mathrm{V}$ par também são responsáveis pela transmissão da sensibilidade à quase toda a face. Um dos locais mais fáceis de verificar se o $\mathrm{V}$ par está funcional é tocando a parte interna das narinas (sempre com luvas em paciente com anormalidade neurológica).

- Sexto par de nervo craniano (VI abducente): movimenta o globo ocular lateralmente, sendo que, lesões nesta região causarão estrabismo (anormalidade da posição do globo ocular) medial. Isto ocorre, pois a musculatura responsável pela sua movimentação para a lateral perde o tônus (contração muscular residual mínima involuntária) e o globo ocular é deslocado para o outro lado.

- Sétimo par de nervo craniano (VII facial): responsável pelo envio das informações motoras que permitem a musculatura movimentar orelhas, pálpebras e lábios. Pode ser avaliado pela observação da simetria facial e ao realizar o reflexo palpebral (o toque na pálpebra é captado pelos receptores que levam informação através do nervo trigêmeo até o tronco encefálico onde o núcleo do nervo facial é estimulado e a informação motora faz com que a musculatura promova o fechamento palpebral).

- Oitavo par de nervo craniano (VIII vestibulococlear): responsável pela transmissão de informações auditivas e contém a porção vestibular que capta informações no ouvido médio/interno. Lesões no VIII par 
podem ocasionar perda auditiva e na porção vestibular levarão aos sinais clássicos de síndrome vestibular.

- Nono par de nervo craniano (XIV glossofaríngeo): quando afetado pode levar à disfagia.

- Décimo par de nervo craniano (X vago): possui importantes funções relacionadas à motilidade dos préestômagos, porém na região da cabeça participa dos movimentos da deglutição e dos músculos da laringe.

- Décimo primeiro par de nervo craniano (XI acessório): raramente é afetado em ruminantes e lesões provocariam atrofia neurogênica no pescoço.

- Décimo segundo par de nervo craniano (XII hipoglosso): inerva predominantemente a musculatura da língua e podemos avaliá-lo verificando a presença do tônus e de atrofias nessa estrutura (Quadro 1).

A lesão em tronco encefálico acarretará alterações em muitos nervos cranianos além de modificação do nível de consciência, funções mantidas pelo tronco encefálico. Por outro lado, lesões em apenas um dos nervos cranianos, especificamente no caso do nervo trigêmeo ou facial, podem eventualmente estar relacio- nadas a uma lesão mais periférica devido ao trajeto destas estruturas.

Quando todas as informações são somadas, verificamos um a um os nervos cranianos, mas agrupando em regiões, teremos a facilidade para realizar a avaliação dos diferentes nervos em conjuntos. Utilize o seguinte exemplo, onde explanaremos a avaliação neurológica que acabamos de descrever. Após cada função avaliada durante o exame clínico colocaremos o nervo craniano responsável entre parênteses. Ao observar um bovino ou ovino, automaticamente você verificará sua simetria facial, posição e movimentação de orelhas e pálpebra (VII par NC), presença de atrofias da musculatura do masseter (porção motora do $\mathrm{V}$ par de $\mathrm{NC}$ ), observará se o animal escutou o ruído durante a sua aproximação (VIII par NC), ele automaticamente se virará para você, deslocará o globo ocular (III, IV e VI pares NC) e, provavelmente o verá (II par de NC juntamente com toda estruturas envolvidas até o córtex occipital). Se este paciente estiver se alimentando você verá a apreensão do alimento com a língua e colocação do

Quadro 1. Principais funções desempenhadas pelos nervos cranianos no SN em ruminantes.
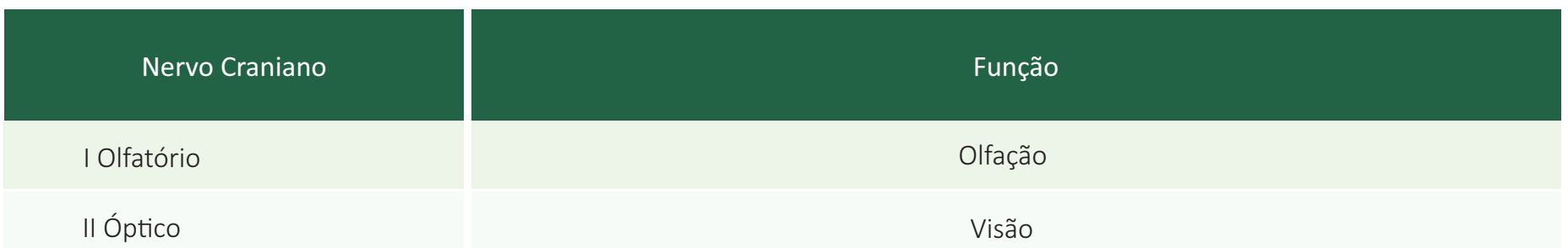

II Óptico

Movimentação e posição ocular e diâmetro da pupila

III Oculomotor

Movimentação e posição ocular

IV Troclear

Musculatura masseter e sensibilidade da face

$\vee$ Trigêmeo

Movimento ocular

VI Abducente

Movimentação de orelha, pálpebra e lábio

VII Facial

Audição e equilíbrio

VIII Vestibulococlear

Deglutição

IX Glossofaríngeo

Deglutição e movimentação da larínge

X Vago

Musculatura pescoço

XI Acessório

Movimentação língua

XII Hipoglosso 
alimento dentro da boca (XII par NC), ele mastigará (porção motora do V par de NC) e, em seguida deglutirá este alimento (IX e X pares de $\mathrm{NC}$ ). Se você chegar mais perto poderá verificar o diâmetro e simetria das pupilas (III par de NC), a posição correta do globo ocular dentro da órbita e sua movimentação ao deslocar a cabeça (III par de NC movimenta globo ocular medialmente; IV par de nervo craniano mantém a rotação correta; VI par de NC movimenta do globo ocular lateralmente e VIII par de NC fornece informações que permitem que o posicionamento seja adotado), você também poderá realizar o reflexo palpebral ( $\mathrm{V}$ par de NC parte sensorial e VII par de NC função motora) e, em seguida verificar se a musculatura do pescoço apresenta atrofia (XI par de NC). A avaliação das funções dos nervos cranianos é simples e já realizada, mesmo que de forma subconsciente, todos os dias pelo veterinário durante o exame clínico. Se, durante a realização do exame for observada alguma anormalidade, basta retornar à descrição da função e correlacionar ao nervo craniano específico (Quadro 2).

Algumas vezes o exame dos nervos cranianos é muito útil para determinação do local da lesão. Já observamos pacientes em decúbito onde ficamos em dúvida se havia alguma alteração encefálica ou se a postura era resultante de uma lesão neuromuscular periférica ou osteomuscular e, após o exame dos nervos cranianos, observamos estrabismos, ou movimentos involuntários do globo ocular que só aparecerão quando lesões em nervos cranianos estiverem presentes.

A partir desta avaliação deveremos ser capazes de dizer se existem anormalidades encefálicas e de preferência estabelecer uma das síndromes a seguir: sindrome cerebral; sindrome vestibular; sindrome de tronco encefálico ou sindrome cerebelar. Os sinais de cada uma delas é descrito no quadro 3.

Lembre-se que ao estabelecer uma síndrome específica e somar aos dados de identificação, anamne-

Quadro 2.Anormalidades nas funções dos nervos cranianos e estruturas responsáveis.

\section{Anomalidades nestas funções...}

Visão

Reposta de ameaça visual

Tamanho e simetria pupilar

Reflexo pupilar

Posição e movimentação do globo ocular

Normalidade e simetria da musculatura facial

Reflexo palpebral

Movimentação da orelha, pálpebra e lábio

Sensibilidade facial

Tônus mandibular normal

Pálpebras são mantidas abertas em posição normal

Resposta normal aos sons

Animal deglute corretamente e move adequadamente a língua

Tônus lingual está normal e a musculatura da língua está simétrica

\section{Sugerem anormalidades nestas estruturas:}

II, córtex occipital (ou as vias entre os dois), olhos

II, VII, cérebro e cerebelo

II, III e sistema nervoso simpático

$$
\text { II e III }
$$

III, IV, VI e VIII

V

Ve VII

VII

V

V

III, VII e sistema nervoso simpático

VIII

IX, X e XII 
Quadro 3. Diferenças dos sinais clínicos nas Síndromes Neurológicas em Ruminantes.

\begin{tabular}{|c|c|c|c|c|}
\hline Síndrome Cerebral & $\begin{array}{c}\text { Síndrome Tronco } \\
\text { Encefálica }\end{array}$ & $\begin{array}{l}\text { Síndrome } \\
\text { Cerebelar }\end{array}$ & $\begin{array}{l}\text { Síndrome Vestibular } \\
\text { central (lesões em tronco } \\
\text { encefálico) }\end{array}$ & $\begin{array}{c}\text { Síndrome Vestibular } \\
\text { periférica (lesões ouvido } \\
\text { interno/nervo vestibular) }\end{array}$ \\
\hline $\begin{array}{l}\text {-Anormalidades } \\
\text { locomotoras discretas: } \\
\text { •Andar compulsivo } \\
\text {-Pressão da cabeça } \\
\text { contra obstáculos } \\
\text {-Andar em círculos } \\
\text { abertos (lesões } \\
\text { unilaterais) } \\
\text {-Alterações } \\
\text { comportamentais } \\
\text { - Convulsões focais ou } \\
\text { generalizadas } \\
\text { - Consciência: diminuída }\end{array}$ & $\begin{array}{l}\text { - Anormalidade em } \\
\text { vários pares de nervos } \\
\text { cranianos } \\
\text { - Paresia ou paralisia } \\
\text { - Diminuição severa nível } \\
\text { consciência }\end{array}$ & $\begin{array}{l}\text { - Anormalidades } \\
\text { locomotoras: } \\
\text { - Ataxia cerebelar } \\
\text { - Hipermetria } \\
\text { - Espasticidade } \\
\text { - Base ampla de } \\
\text { apoio } \\
\text { - Tremores de } \\
\text { intenção cabeça }\end{array}$ & $\begin{array}{l}\text { - Perda de equilíbrio: ataxia } \\
\text { vestibular } \\
\text { - Nistagmos rotatórios ou } \\
\text { verticais } \\
\text { - Rotação da cabeça } \\
\text { ("head tilt") } \\
\text { - Consciência: diminuída }\end{array}$ & $\begin{array}{l}\text { - Perda de equilíbrio: ataxia } \\
\text { vestibular } \\
\text { - Nistagmos horizontais } \\
\text { - Rotação da cabeça } \\
\text { ("'head tilt") } \\
\text { - Reações posturais: } \\
\text { normal } \\
\text { - Propriocepção: normal } \\
\text { - Consciência: normal }\end{array}$ \\
\hline
\end{tabular}

se e evolução da lesão, você terá grandes chances de estabelecer uma lista de diagnósticos diferenciais adequada. Algumas vezes é possível ter lesões multifocais ou difusas, onde diferentes aspectos destas síndromes estarão presentes. Particularidades importantes existem na síndrome vestibular, onde é possível subdividi-la em síndrome vestibular periférica e síndrome vestibular central, sempre que possível, é importante diferenciálas para que possamos refinar os diagnósticos diferenciais.

\section{- Avaliação da medula espinhal e cauda equina}

Para avaliação da medula espinhal devemos inicialmente descartar as anormalidades osteomusculares que são as causas mais frequentes das alterações locomotoras.

A suspeita de uma anormalidade na medula espinhal ocorre sempre que existe uma alteração no padrão de locomoção ou quando o paciente estiver em decúbito. A locomoção é iniciada voluntariamente em núcleos motores localizados no encéfalo, portanto, lesões encefálicas podem alterar o padrão locomotor ou levar o paciente ao decúbito. Porém, os sinais de anormalidades em nervos cranianos, alterações comportamentais e do nível de consciência deverão estar presentes. As lesões na medula espinhal, alterarão tanto o envio de mensagens motoras aos músculos, quanto a chegada de informações de sensibilidade ou proprioceptivas que serão interpretadas no encéfalo. Lesões discretas poderão levar à incoordenação motora de origem neurológica e lesões mais graves levarão o paciente ao decúbito. Portanto, a incoordenação motora de origem neurológica é um conjunto de sinais caracterizados por perdas motoras (paresia) e sensoriais (ataxia).

Para interpretar o exame de um paciente com alteração da medula espinhal usualmente precisamos compreender como a locomoção ocorre. Inicialmente, os núcleos encefálicos dos neurônios motores superiores dentro do encéfalo iniciam a atividade locomotora e esta é transmitida pela medula espinhal até fazer conexão com outro neurônio motor (inferior) e ser encaminhada ao músculo. Logicamente que informações sensoriais e proprioceptivas originadas em receptores de tendões, músculos e articulações são encaminhadas também por neurônios sensoriais do nervo periférico e depois pela medula espinhal até serem interpretadas no encéfalo.É este balanço entre informações proprioceptivas (que contém dados sobre o posicionamento) e informações motoras que permite um padrão de locomoção normal, de uma forma bem simplificada.Porém, para localizar a lesão dentro da medula espinhal precisamos utilizar o conceito de neurônios motores superiores e inferiores que nos permite, especialmente em um paciente com menos de $100 \mathrm{~kg}$, uma localização mais 
segura da lesão dentro das diferentes regiões da medula espinhal: C1-C5, C6-T2,T3-L3,L4-S2 e S3-Co.

Para compreendermos como realizar esta localização, precisamos rever o conceito de neurônio motor superior e inferior (Figura 9).

Neurônios motores superiores (NMS) são neurônios que possuem duas funções principais: transmitir informação motora gerada no encéfalo para um neurônio motor inferior (NMI) e, modular inibitoriamente neurônios motores inferiores. O núcleo do NMS está localizado no encéfalo e seu neurônio, que nunca sai do $\mathrm{SNC}$, está também localizado em tratos motores na medula espinhal. O NMI, por outro lado, é o neurônio que recebe informação do NMS e a encaminha ao músculo. Além disso, a despolarização do NMI mantém o tônus muscular. Os neurônios motores inferiores podem apresentar duas distribuições:

- NMI dos nervos espinhais: neste caso o núcleo do NMI está localizado na porção ventral da substância cinzenta da medula espinhal e seu axônio sai pela raiz ventral e está contido no nervo periférico.

- NMI dos nervos cranianos: os nervos cranianos motores têm seu núcleo localizado no tronco encefálico e seu axônio no nervo craniano.

Relembrando um pouco a neuroanatomia. $\mathrm{O}$ NMS que leva as informações para movimentação dos membros torácicos, se conecta aos NMI na região de C6-T2. Esta região é importante e tem uma grande densidade de conexões e, portanto, existe um aumento do diâmetro medular denominado intumescência cérvico-torácica. Já as informações levadas aos membros pélvicos pelos NMS, encontram os NMI na região de L4-S2, sendo esta região com grande densidade neuronal denominada de intumescência lombo-sacra (Figura 9).

Como utilizar este sistema para localizar as lesões? Para isso é necessário lembrar que lesões de NMI levam à diminuição da movimentação voluntária (denominada de paresia) ou ausência de movimentação voluntária (paralisia). Isto acontece, pois as informações não chegam ao músculo. Ocorre também diminuição ou ausência do tônus, pois os NMI despolarizam para manter o tônus muscular (por isso denominamos esta paresia ou paralisia de flácida). Outro aspecto

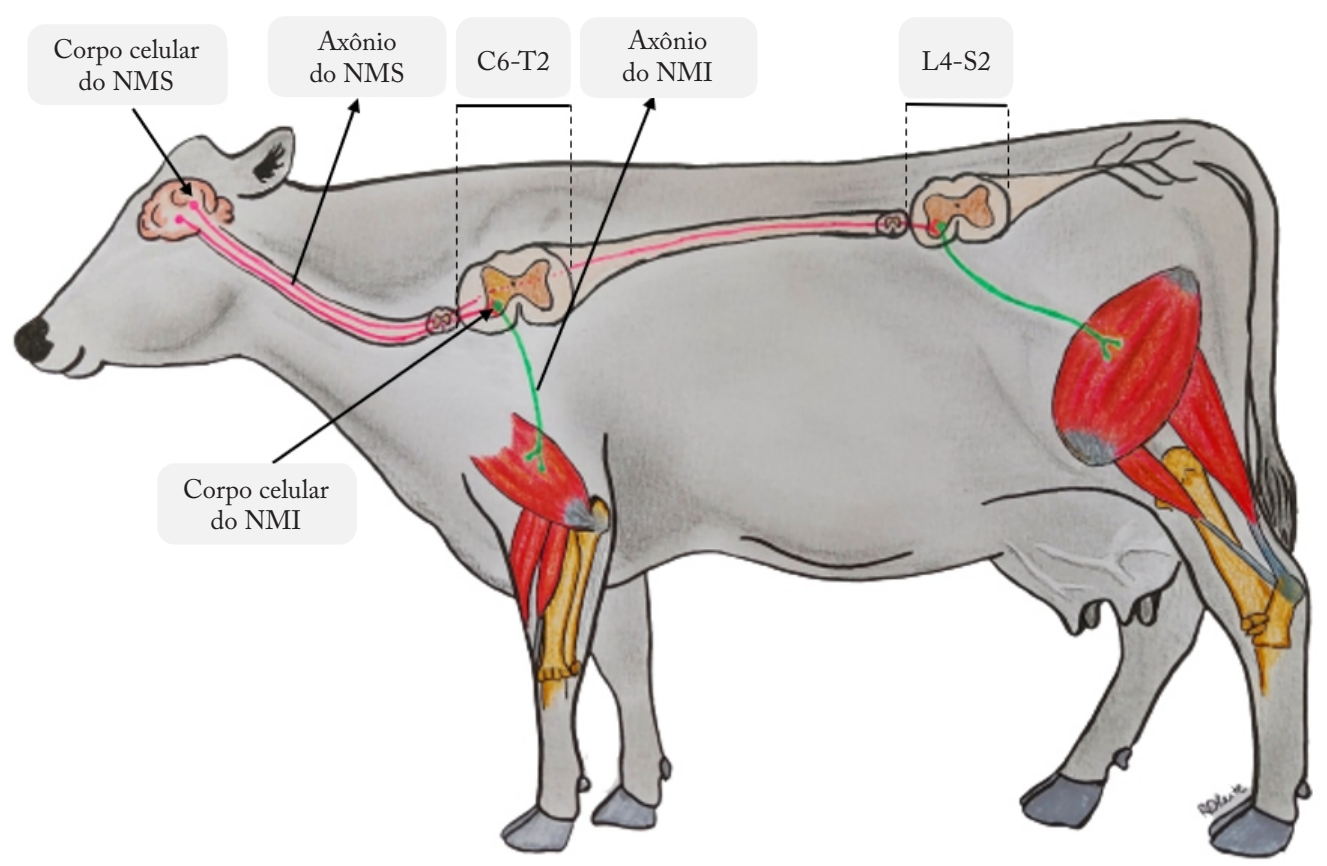

Figura 9. Neurônio Motor Superior (NMS): possui corpo celular no encéfalo e axônio na medula espinhal levando informações que são transmitidas para o neurônio inferior na região de C6-T2 para os membros torácicos, e na região L4-S2 para os membros pélvicos. Neurônio Motor Inferior (NMI): possui corpo celular na porção ventral da substância cinzenta da medula espinhal e transportam os sinais da medula espinhal para os efetores (músculos). O axônio do NMI espinhal está dentro de um nervo periférico. 
importante é a diminuição dos reflexos pois, se o NMI não funciona adequadamente, o arco reflexo não é completado de forma adequada (sendo o termo hiporreflexia utilizado para diminuição dos reflexos ou arreflexia para ausência dos reflexos). Em resumo, lesões de NMI levam à paralisia ou paresia do tipo flácida. Já as lesões do NMS também acarretam paresia ou paralisia (já que as informações não chegam aos NMI de forma correta), mas neste caso, teremos tônus e os reflexos poderão ser normais (normorreflexia) ou aumentados (hiperreflexia), porém nunca diminuídos.

Por que ocorre o aumento dos reflexos? Lembre-se que uma das funções do NMS é modular inibitoriamente os conjuntos neuronais e, se estes não foram modulados, estarão mais responsivos aos estímulos e, portanto, os reflexos estarão aumentados (Quadro 4).

Sendo assim, lesões de L4-S2 como afetam primariamente os núcleos dos NMI na região cinzenta da medula espinhal dos membros pélvicos, levarão a uma paraparesia (paresia dos membros pélvicos) ou paraplegia (paralisia dos membros pélvicos) com diminuição ou ausência de tônus e reflexos.

O paciente com lesões nos segmentos medulares de T3-L3, também apresentará paraparesia ou paraplegia (quanto mais grave a lesão, maiores as chances de o paciente apresentar paralisia) do tipo espástica, onde temos reflexos e tônus, aumentados ou normais. Isto ocorre pois o NMS não transmitirá as informações motoras e não modulará inibitoriamente o NMI. Aqui vale ressaltar que a espasticidade pode ser observada, principalmente, com paciente em decúbito lateral onde teremos dificuldade para movimentar e fletir o membro e, geralmente, quando realizamos a flexão do membro ele retorna à extensão logo em seguida. Esta espasticidade não é tetânica e sim, um aumento do tônus que permite a flexão, mas com maior resistência.

- Lesões de C6-T2: provocarão anormalidades nos quatro membros (tetraparesia ou tetraplegia), sendo que os torácicos se apresentarão flácidos e os pélvicos espásticos. Isto ocorre pois, lesões de C6-T2 afetarão os corpos celulares do NMI dos membros torácicos e dos NMS que iam aos membros pélvicos, provocando uma falta de inibição e de transmissão motora adequada.

- Lesões de C1-C5: acarretarão tetraparesia ou tetraplegia com espasticidade nos quatro membros (lembre-se que ao ter espasticidade ocorrerá também aumento de reflexos e neste caso nos quatro membros).

O examinador observará que existem formas menos específicas, mas que podem ser úteis em animais muito pesados onde teremos dificuldade para testar tônus e reflexos. Por exemplo:

- Lesões cervicais graves altas em C1-C2: o paciente permanecerá em decúbito lateral e não conseguirá retirar a cabeça do chão.

- Lesões graves em C3-C7: usualmente o paciente movimenta a cabeça, mas não retira o pescoço do chão.

- Lesões em C1-T4: o animal não consegue permanecer em decúbito esternal.

- Lesões caudais à T5: é possível o animal sair do decúbito lateral e ir para o decúbito esternal.

Quadro 4. Resumo dos sinais decorrentes de lesão no Neurônio Motor Superior (NMS) ou Neurônio Motor Inferior (NMI).

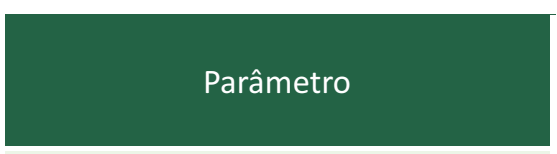

Função motora

Reflexos

Atrofia muscular

Tônus muscular

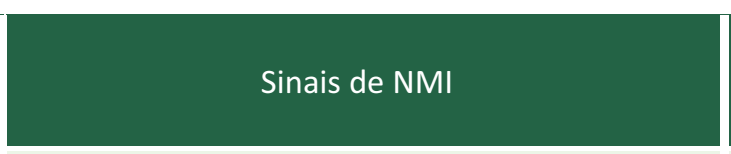

Paresia e paralisia

Hiporreflexia e arreflexia Neurogênica: rápida e facilmente perceptível Diminuído (flacidez)

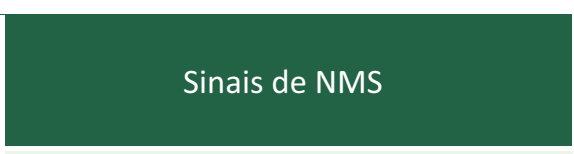

Paresia e paralisia

Normais e hiperreflexia

Lento

Normal a aumentado (espasticidade) 
- Lesões em cauda equina: frequentemente observada em ovinos após procedimentos de caudectomia que infeccionam. Inicialmente não apresentam alterações locomotoras e sim, diminuição do tônus do ânus, sensibilidade perineal e incontinência urinária (síndrome da cauda equina). Se esta lesão progredir cranialmente na medula espinal e chegar aos segmentos de L4 a S2, surgirão anormalidades locomotoras.

Quais reflexos são usualmente testados em animais de grande porte? Usualmente testamos o reflexo patelar, reflexo flexor nos membros pélvicos, reflexo carpo radial e o reflexo flexor nos membros torácicos (Figura 10).

Outros reflexos podem ser testados, mas a avaliação torna-se difícil, especialmente em animais de maior peso, sendo eles:

- Membro pélvico: reflexo tibial cranial, reflexo ciático superior, reflexo gastrocnêmio.

- Membro torácico: reflexo bicipital e reflexo tricipital.

Todos estes reflexos são testados rotineiramente em cães e gatos, mas não necessariamente em pacien- tes de grande porte.

Não podemos nos esquecer que mesmo uma lesão em um nervo periférico no membro torácico ou pélvico pode acarretar decúbito ou eventualmente uma lesão na coluna vertebral com discreta compressão. $\mathrm{O}$ problema destas lesões é que o paciente muitas vezes entra em decúbito e não consegue mais se levantar e a compressão muscular e nervosa causada pelo contato prolongado com uma superfície mais dura do local que ele esteja pode levar às lesões secundárias. Sendo assim, sempre que possível ao avaliar um paciente em decúbito, procuramos colocá-lo em posição quadrupedal, para que possamos avaliar sua resposta e a manutenção do tônus nos diferentes membros. Alguns pacientes só apresentam uma resposta adequada após várias horas em suspensor ou mesmo após alguns dias sendo mantido em maca (revezando com o decúbito em superfície a mais macia possível, como capim, maravalha, etc).

Sabemos que nem sempre este tipo de manejo é possível em propriedades rurais. Outro ponto importante a ser considerado, é que muitas vezes pacientes

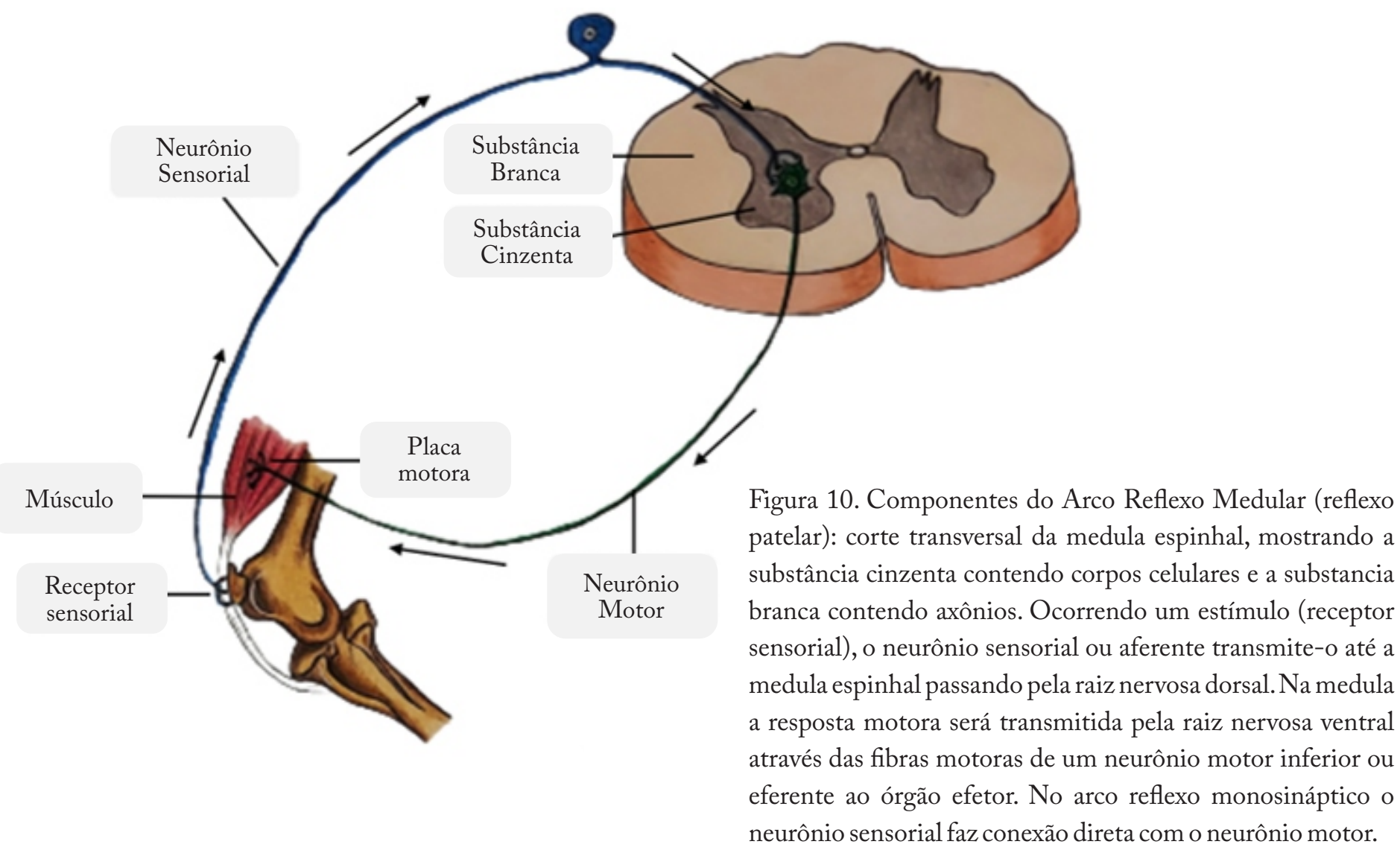


em decúbito ficam sem ter acesso à água, ocasionando desidratação o que pode deixar o clínico em dúvida sobre seu nível de consciência. A Figura 11 ilustra um tipo de suporte para manutenção dos bovinos suspensos.

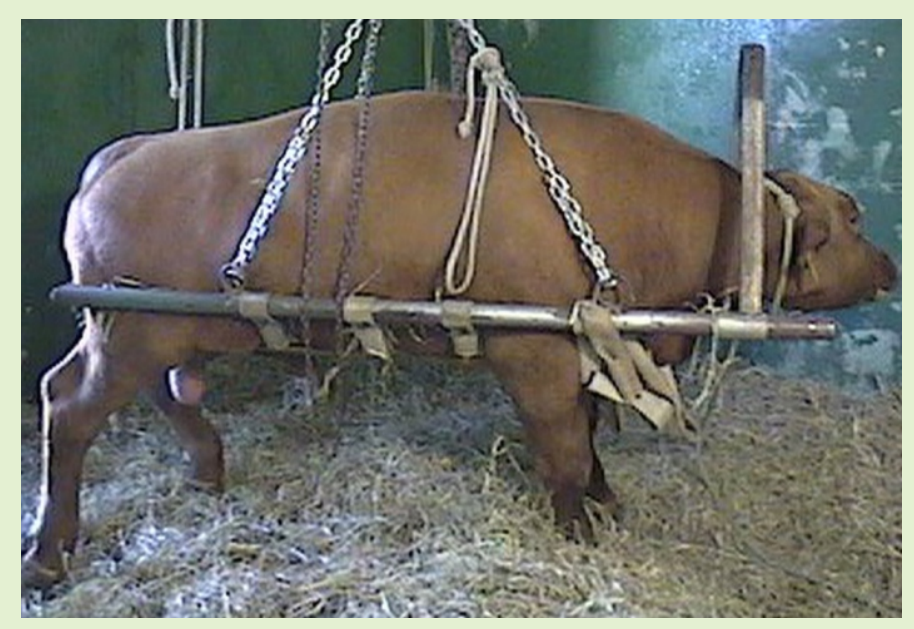

Figura 11. Exemplo de aparelho para manter bovino suspenso utilizado na UNESP Campus de Botucatu/SP.
Com esta breve explicação do exame neurológico de grandes animais temos como objetivos facilitar que o examinador consiga traçar uma lista de diagnósticos diferenciais pois será mais fácil localizar a lesão. Isto também fornecerá dados úteis para aqueles pacientes que vieram à óbito ou que venham a ser sacrificados, pois a colheita de regiões específicas do sistema nervoso, oferece ao patologista amostras com maior probabilidade de conter anormalidades e assim chegar ao diagnóstico.

A abordagem descrita no exame neurológico é referente a experiência dos autores deste trabalho. Muitos outros detalhes podem ser obtidos no exame neurológico e para aqueles interessados em informações adicionais, sugerimos consultar a literatura presente no Quadro 5.

Quadro 5. Relação de livros, capítulos e artigos que abordam o exame neurológico de ruminantes.

\section{LITERATURA ADICIONAL}

Exame Neurológico em Ruminantes

BORGES, A. S.; MENDES, L. C. N.; KUCHEMBUCK, M. R. G. Exame Neurológico de Grandes Animais. Parte I: Encéfalo. Revista de Educação Continuada em Medicina Veterinária e Zootecnia do CRMV-SP., v.2, n.3,p.4-16,1999.

BREWER, B. D. Examination of the Bovine Nervous System. Veterinary Clinics of North America: Food Animal Practice., v. 3, n.1, p.13-24,1987.

DE LAHUNTA, A.; GLASS, E. Veterinary Neuroanatomy and Clinical Neurology. 3ed. St. Louis: W. B. Saunders, 544p., 2009.

FECTEAU, G.; PARENT,J.; GEORGE,L.W.Neurologic Examination of the Ruminant. Veterinary Clinics of North America: Food Animal Practice, v. 33, n.1,p.1-8,2017.

MAYHEW, J. Large Animal Neurology. 2ed. Oxford: Wiley- Blackwell, 46p., 2008.

SHERMAN, D. M. The Role of Clinical Examination in the Accurate Diagnosis of Bocine Neurologic Disease. Veterinary Clinics of North America: Food Animal Practice, v.3, n.1, p-1-12, 1987.

THOMSON, C.; HAHN, C. Veterinary Neuroanatomy. A Clinical Approach.1ed.London: Saunders Elsevier, 178 p., 2012. 


\section{DOENÇAS NEUROL
DE RUMINANTES NO BRASIL}

nóstico diferencial para as demais doenças representa desafio muito maior, pois depende da aplicação de métodos laboratoriais variados e específicos para cada enfermidade. Neste sentido, todos estes estudos de casuística em bovinos, são muito relevantes porque contribuem com informações epidemiológicas atualizadas.

Considerando-se os resultados dos estudos de

As informações de levantamentos sobre a ocorrência das doenças neurológicas em ruminantes são mais numerosas em bovinos e são escassas em pequenos ruminantes. Os autores desta revisão desconhecem a divulgação de estudos específicos de casuística sobre estas enfermidades em búfalos. Os levantamentos em bovinos se concentraram na última década e abrangeram os estados do $\mathrm{RS}^{1-4}, \mathrm{~PB}, \mathrm{PE}$ e $\mathrm{RN}$, agrupados como a região semiárida do Nordeste ${ }^{5}, \mathrm{MS}^{6}, \mathrm{MG}^{7}, \mathrm{GO}^{8}$ e $\mathrm{PR}^{9}$. Os levantamentos em ovinos e caprinos, por outro lado, foram realizados somente no semiárido nordestino ${ }^{10}$ e no $\mathrm{RS}^{3,11,12}$.

O maior interesse pelos bovinos se deve a ocorrência destas doenças nessa espécie e isso, certamente, facilita a reunião de número expressivo de observações. É natural que sejam observadas mais frequentemente em bovinos uma vez que o rebanho é muito maior do que o das demais espécies de ruminantes. De qualquer forma, a vigilância epidemiológica para as doenças neurológicas dos bovinos necessita manter-se intensificada em virtude da Encefalopatia Espongiforme Bovina (EEB), doença que provoca a imposição de barreiras à exportação da carne. É tão importante comprovarmos que não ocorre a EEB no país quanto demonstrarmos quais doenças neurológicas são prevalentes. A cadeia de vigilância epidemiológica para a raiva dos herbívoros é bem estruturada e executada pelos serviços oficiais de defesa sanitária de cada Estado. Contudo, o diagcasuística que investigaram doenças neurológicas em bovinos sem distinção por idade e sem exclusão de alguma enfermidade específica, podem-se reunir as observações em 1.532 animais criados no $\mathrm{RS}^{2}, \mathrm{~PB}, \mathrm{PE}$ e $\mathrm{RN}^{5}, \mathrm{MS}^{6}, \mathrm{GO}^{8}$ e $\mathrm{PR}^{9}$, e estabelecer, livremente, a distribuição de frequências. É claro que o resultado apresentado a seguir não é representativo fiel do país inteiro e não abrange as regiões Sudeste e Norte. Além disso, deve-se levar em conta que existem particularidades regionais, estaduais e locais importantes que determinam diferenças específicas na prevalência de determinadas doenças. Entretanto, estas são as informações disponíveis e podem ser entendidas como conceito geral.

As doenças inflamatórias do SNC de bovinos, representadas principalmente pela encefalite e raramente pela mielite, são predominantes e representam $50 \%$ de todos os casos. Dentre elas, as provocadas por agentes virais são muito frequentes $(44,5 \%)$ e as causadas por bactérias têm baixa prevalência $(5,5 \%)$ (Figura 12).

A raiva é a doença mais prevalente (28\%) e isto foi confirmado em todos os estudos, aparecendo em primeiro $^{2,5,8}$ ou em segundo lugares ${ }^{6,9}$. A encefalite provocada por BoHV-5 (Herpesvírus Bovino tipo-5), e eventualmente por BoHV-1 (Herpesvírus Bovino tipo 1), é a segunda doença mais importante neste grupo, representando $10 \%$ de todos os casos. Isto foi con- 


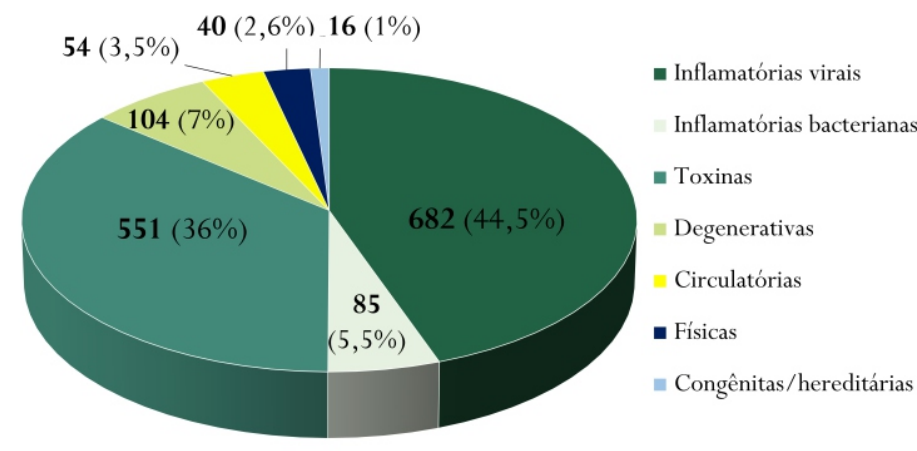

Figura 12. Causas de doenças neurológicas em bovinos. Reunião dos estudos de casuística realizados nos estados do $\mathrm{RS}^{2}$, $\mathrm{PB}^{5}, \mathrm{PE}^{5}, \mathrm{RN}^{5}, \mathrm{MS}^{6}, \mathrm{GO}^{8}$ e $\mathrm{PR}^{9}$.

sistentemente demonstrado nos levantamentos do $\mathrm{RS}^{2}$, $\mathrm{MS}^{6}, \mathrm{GO}^{8}$ e $\mathrm{PR}^{9}$, porém, não no semiárido nordestino ${ }^{5}$. Os casos de meningoencefalite não supurativa inespecífica, ou seja, nos quais o agente causador não foi definido, aparecem em terceiro lugar de importância dentre as doenças inflamatórias (4\% de todos os casos). É coerente supor que o Herpesvírus Bovino (BoHV-5 e/ou BoHV-1) estivesse envolvido em boa parte destes casos, mas, por motivos diversos, não tenha sido confirmado por métodos laboratoriais específicos. Por fim, a Febre Catarral Maligna (FCM) representa 2,4\% dos casos, aparecendo em todos os levantamentos, com destaque para os do $\mathrm{RS}^{2}$ e do semiárido nordestino ${ }^{5}$ (Figura 13).

Dentre as encefalites ou mielites de origem bacteriana destacam-se os abscessos cerebrais, medulares ou do canal vertebral com compressão da medula espinhal (2,8\% de todos os casos) e os casos de meningoencefalite supurativa não organizada na forma de abscessos (1,4\% de todos os casos). A histofilose, também denominada de meningoencefalite tromboembólica ou trombótica, representa $0,8 \%$ dos casos e teve prevalência mais destacada no estudo paranaense 9 . Finalmente, a listeriose representa somente 0,6\% dos casos, tendo sido observada em quase todos os Estados, e sempre com prevalência reduzida ${ }^{2,5,7-9}$ (Figura 13).

Este fato é relevante porque a listeriose é apontada como a principal causa de encefalite em bovinos nos países de clima temperado e frio do hemisfério norte $^{13}$. Por este motivo, recebe destaque justificado nos livros textos tradicionais originários destes países. $\mathrm{O}$ buiatra brasileiro precisa entender que, com base nas evidências dos estudos nacionais, a listeriose é certamente uma doença pouco importante em bovinos. Até mesmo em um estudo de casos específicos de doenças bacterianas do SNC, realizado no $\mathrm{RS}$, a listeriose representou $14 \%$ das encefalites bacterianas e 1,8\% de todos os casos de doenças inflamatórias do SNC de bovinos ${ }^{3}$. Resultados muito parecidos foram observados no estudo de casuística de doenças neurológicas de bezerros até um ano de idade, realizado no RS. Eliminando-se o tétano das doenças bacterianas, a listeriose representou $13 \%$ das encefalites bacterianas e $1,8 \%$ de todos os casos $^{4}$.

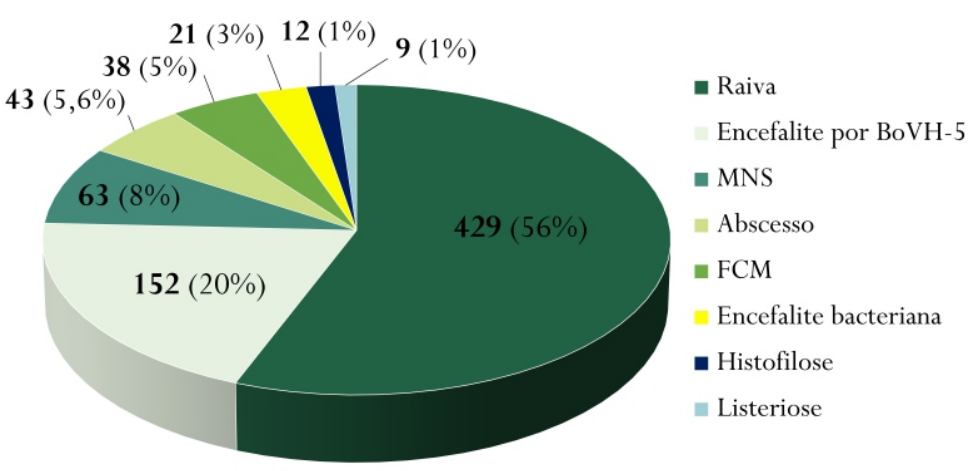

Figura 13. Doenças inflamatórias do SNC de bovinos. Reunião dos estudos de casuística realizados nos estados do $\mathrm{RS}^{2}, \mathrm{~PB}^{5}$, $\mathrm{PE}^{5}, \mathrm{RN}^{5}, \mathrm{MS}^{6}, \mathrm{GO}^{8}$ e $\mathrm{PR}^{9}$. MNS: Meningoencefalite Não Supurativa e FCM: Febre Catarral Maligna.

As doenças tóxicas ocorrem em segundo lugar de importância (36\% dos casos) (Figura 12). Deve-se esclarecer que o tétano e o botulismo foram arbitrariamente computados dentro deste grupo de enfermidades, uma vez que as disfunções neurológicas são provocadas pelas toxinas bacterianas. Não pretendemos aqui sugerir novo modo de classificação, mas que nesta revisão foi adotada para que pudéssemos subdividir de modo prático as diferentes enfermidades. Dentre as doenças, destacam-se o botulismo (16,7\% de todos os casos), que teve prevalência muito elevada no estudo do $\mathrm{MS}^{6}$, e a encefalopatia hepática secundária à intoxicação por plantas hepatotóxicas $(11,5 \%$ de todos os 
casos), notadamente Senecio brasiliensis, cuja ocorrência foi muito alta no estudo do $\mathrm{RS}^{2}$. As intoxicações por plantas com ação direta sobre o SNC representam 4,5\% de todos os casos e foram observadas, principalmente, nos estudos do $\mathrm{RS}^{2}$ e do $\mathrm{PR}^{9}$. As intoxicações por plantas são causas relevantes de doença neurológica nos bovinos e coletivamente representam quase metade das ocorrências de causas tóxicas (44,6\%) e 16\% de todos os casos. A intoxicação por compostos químicos, considerando-se as possibilidades de intoxicação por ureia (amônia) ${ }^{8}$, nitrito, $\mathrm{NaCl}$, carbamato ou organofosfora$\mathrm{do}^{9}$, tem ocorrência reduzida (1,3\% de todos os casos). Em situações específicas, contudo, podem assumir importância destacada dentro de um rebanho quando ocorrem na forma de surto, causando a morte rápida de número elevado de animais. Diferente do que se observa nos equídeos, o tétano geralmente ocorre com frequência reduzida nos bovinos, representando 1,7\% de todos os casos (Figura 14).

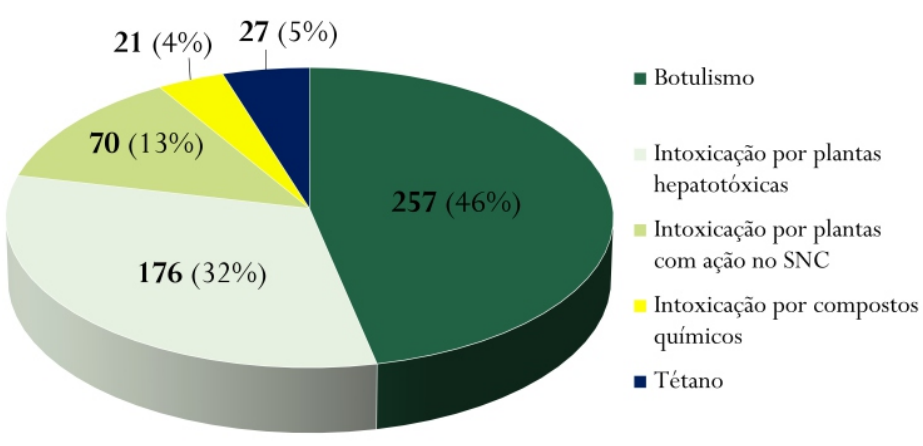

Figura 14. Doenças tóxicas que determinam disfunções neurológicas em bovinos. Reunião dos estudos de casuística realizados nos estados do $\mathrm{RS}^{2}, \mathrm{~PB}, \mathrm{PE}$ e $\mathrm{RN}^{5}, \mathrm{MS}^{6}, \mathrm{GO}^{8}$ e $\mathrm{PR}^{9}$.

Por definição, polioencefalomalacia (PEM) é um processo patológico que significa necrose da substância cinzenta do encéfalo, o qual ocorre em diferentes enfermidades, tais como, metabolismo alterado da tiamina, excesso de ingestão de enxofre, intoxicação por $\mathrm{NaCl}$ associada à privação de água, intoxicação por chumbo e meningoencefalite por BoHV- $5^{14}$. Na presente revisão o termo PEM será utilizado para representar doença provocada pelo metabolismo alterado da tiamina ou por ingestão excessiva de enxofre. As demais enfermidades que determinam este tipo de alteração no encéfalo podem ser confirmadas por métodos específicos garantindo o diagnóstico diferencial.

A PEM é uma doença neurológica degenerativa relevante nos bovinos e representa $6,8 \%$ de todos os casos (Figura 12). Foi diagnosticada em todos os levantamentos estaduais realizados com destaque para o $\mathrm{MS}^{6}$ e GO$^{8}$, cujas frequências de ocorrência foram $13 \%$ e $17 \%$, respectivamente. Nos demais estudos, a doença ocorreu com taxas menores, variando entre 1,8\% e $3,8 \%$ dos $\operatorname{casos}^{2,4,5,9}$. No levantamento realizado em MG, no qual os casos de raiva não foram incluídos, a PEM representou $11 \%$ de todos os casos investigados .

A babesiose cerebral é provocada pela infecção por Babesia bovis e ocorre com prevalência de 3,5\% nos levantamentos brasileiros agrupados. Está apresentada nesta revisão como causa circulatória de doença neurológica dos bovinos (Figura 12). Foi observada em todos os Estados estudados, com exceção de $\mathrm{GO}^{8}$, com taxas de prevalência reduzidas, variando entre 0,9 e 2,1\%. No $\mathrm{RS}$, a situação se distingue, alcançando frequências de 6,5\% dos casos em bovinos de todas as idades ${ }^{2}$ e de $16 \%$ dos casos em bezerros até os doze meses de idade ${ }^{4}$. No estudo de $\mathrm{MG}$, em que a raiva foi excluída, a doença ocorreu em 12,3\% dos casos $^{7}$. Trata-se de uma enfermidade mais relevante nas regiões de clima mais frio, caracterizadas como zonas de instabilidade enzoótica para a Tristeza Parasitária Bovina (anaplasmose e babesioses), onde a população do carrapato vetor Rhipicephalus microplus oscila muito ao longo dos meses do ano. Por outro lado, o deslocamento dos bovinos de áreas de instabilidade (clima frio) para áreas de estabilidade enzoótica (clima quente) é um fator de risco importante e, na experiência prática dos autores, esta situação é observada no estado do PR com certa frequência.

Por fim, os traumatismos cranianos e de coluna vertebral determinando disfunções neurológicas secundárias podem ocorrer com frequência equivalente a 2,6\% de todos os casos (Figura 12).

As principais doenças neurológicas dos bovinos estão apresentadas no Quadro 6 por ordem decrescente de ocorrência. 
Quadro 6. Principais doenças neurológicas em bovinos apresentadas por ordem decrescente de ocorrência. Reunião dos estudos de casuística realizados nos estados do $\mathrm{RS}^{2}, \mathrm{~PB}, \mathrm{PE}$ e $\mathrm{RN}^{5}, \mathrm{MS}^{6}, \mathrm{GO}^{8}$ e $\mathrm{PR}^{9}$.

\begin{tabular}{|c|c|c|}
\hline Ordem & $\%$ & Enfermidade \\
\hline 1 & 28,0 & Raiva \\
\hline 2 & 16,7 & Botulismo \\
\hline 3 & 11,5 & Encefalopatia hepática (intoxicação com plantas hepatotóxicas) \\
\hline 4 & 9,9 & Meningoencefalite por BoHV-5 \\
\hline 5 & 6,8 & Polioencefalomalacia \\
\hline 6 & 4,5 & Intoxicação com plantas com ação direta sobre o SNC \\
\hline 7 & 4,0 & Meningoencefalite não supurativa (agente causador não esclarecido) \\
\hline 8 & 3,5 & Babesiose cerebral \\
\hline 9 & 2,8 & Abscessos no SNC (encéfalo ou medula) ou no canal vertebral \\
\hline 10 & 2,6 & Traumatismos no crânio ou na coluna vertebral \\
\hline 11 & 2,4 & Febre Catarral Maligna \\
\hline 12 & 1,7 & Tétano \\
\hline 13 & 1,4 & Meningoencefalite bacteriana (não organizada em abscesso) \\
\hline 14 & 1,3 & Intoxicação com compostos químicos diversos \\
\hline 15 & 1,0 & Doenças congênitas e/ou hereditárias do SNC \\
\hline 16 & 0,8 & Histofilose \\
\hline 17 & 0,6 & Listeriose \\
\hline
\end{tabular}

Não se pode esquecer que existem condições relevantes que influenciam a prevalência e incidência regionais destas enfermidades. A julgar pelos dados publicados pelo Ministério da Agricultura Pecuária e Abastecimento, em seu sítio eletrônico (e), sobre os casos de raiva diagnosticados nas espécies herbívoras domésticas em cada estado e a cada ano, é certo afirmar que esta é, de fato, a principal doença neurológica dos bovinos no Brasil, ocorrendo em todos os Estados da
União.

Por outro lado, deve-se considerar que as ocorrências de botulismo e de encefalopatia hepática devida, principalmente, à intoxicação por Senecio brasiliensis, devem estar superestimadas nesta casuística reunida. Estas duas enfermidades ocorreram com frequências muito elevadas nos levantamentos do $\mathrm{MS}^{6}$ e do $\mathrm{RS}^{2}$, respectivamente, mas isto não representa a situação vigente nos demais estados ou regiões. O botulismo, 
por exemplo, representou 30\% dos casos com diagnóstico concluído no $\mathrm{MS}^{6}$, mas a sua frequência foi sempre mais reduzida nos levantamentos dos demais Estados: 6,3\% no semiárido nordestino ${ }^{5}, 5,9 \%$ em GO $^{8}, 3,4 \%$ no $\mathrm{PR}^{9}$ e $0,9 \%$ no $\mathrm{RS}^{2}$. A encefalopatia hepática, por outro lado, foi observada exclusivamente nos levantamentos do RS, representando $24 \%$ dos casos ${ }^{2}$, e do PR, representando 5,9\% dos casos $^{9}$. A intoxicação por Senecio brasiliensis, principal responsável por estes casos de encefalopatia hepática, pode ser esperada unicamente nos estados da região Sul e em SP, devido à distribuição geográfica desta planta invasora ${ }^{15}$.

No caso específico das plantas tóxicas, as disfunções neurológicas podem ser provocadas por plantas que determinam lesão hepática aguda ou crônica (encefalopatia hepática), e por plantas que possuem princípios tóxicos que afetam diretamente o SNC. Estas últimas podem ser agrupadas em:

A plantas que causam doenças do armazenamento em neurônios,

B plantas que causam síndrome tremorgênica,

C plantas que causam lesões localizadas no SNC,

D plantas com outras ações neurológicas,

E plantas que albergam fungos produtores de micotoxinas com ação sobre o $\mathrm{SNC}^{15}$.

No Brasil, há 31 espécies de plantas tóxicas que afetam o SNC reconhecidas atualmente, e quase todas provocam doença em ruminantes. A última revisão sobre o assunto está disponível para consulta ${ }^{16}$.

As distribuições geográficas destas plantas variam consideravelmente, o que explica prevalências tão distintas em diferentes Estados ou regiões do país. Nesta revisão, este assunto não será explorado de maneira aprofundada, apesar de sua relevância incontestável dentre as doenças neurológicas dos ruminantes. As intoxicações por plantas representam um grupo numeroso de doenças específicas o que tornaria o texto muito extenso. Os leitores interessados podem encontrar informações detalhadas e atualizadas sobre as plantas, áreas em que ocorrem, princípios tóxicos, sinais clínicos e evolução, lesões e diagnóstico nos textos de Tokarnia et al. ${ }^{15}$ e de Riet-Correa et al. ${ }^{16}$. É imprescindível que o clínico buiatra mantenha-se suficientemente informado sobre as plantas tóxicas presentes na área de abrangência de sua atuação, sabendo reconhecê-las e entendendo os problemas de saúde que provocam nos animais.

Em relação às intoxicações com plantas, merecem destaque, também, as plantas miotóxicas, tais como Senna occidentalis e Senna obtusifolia.

As mesmas não provocam distúrbios neurológicos, mas causam necrose da musculatura esquelética e incapacidade funcional, que determina o decúbito permanente. Por este motivo, entram obrigatoriamente na lista de diagnósticos diferenciais das doenças neurológicas dos bovinos. Além disso, bovinos intoxicados com Senna obtusifolia podem apresentar encefalopatia hepática, uma vez que a planta também possui potencial hepatotóxico ${ }^{17}$.

Do ponto de vista de importância epidemiológica e econômica, destacam-se as doenças que podem ocorrer na forma de surtos, causando a morte de número elevado de bovinos. A raiva tem importância ainda maior por ser zoonose. As doenças dos bovinos que podem ocorrer como surtos são raiva, botulismo, encefalopatia hepática, meningoencefalite por BoHV-5, PEM, intoxicação por plantas com ação direta sobre o SNC, babesiose cerebral, FCM e histofilose. Casos isolados destas doenças também podem ser vistos. Ao contrário, as doenças que exclusivamente ou mais frequentemente aparecem como casos isolados são traumatismos, tétano, abscessos ou meningoencefalite bacteriana e listeriose. Nos casos das enfermidades do primeiro grupo, as orientações de medidas de controle e de prevenção são indispensáveis. Isto não é verdade para os casos de traumatismos e de meningoencefalite bacteriana (organizada como abscessos ou não), pois, comumente, afetam um único bovino no rebanho.

Dentre as doenças neurológicas dos ovinos registradas no Brasil, destacam-se as inflamatórias causadas por infecção bacteriana e, ao contrário dos bovinos, a encefalite viral tem pouca importância epidemiológica (Figura 15).

No estudo de casuística sobre meningoencefa- 


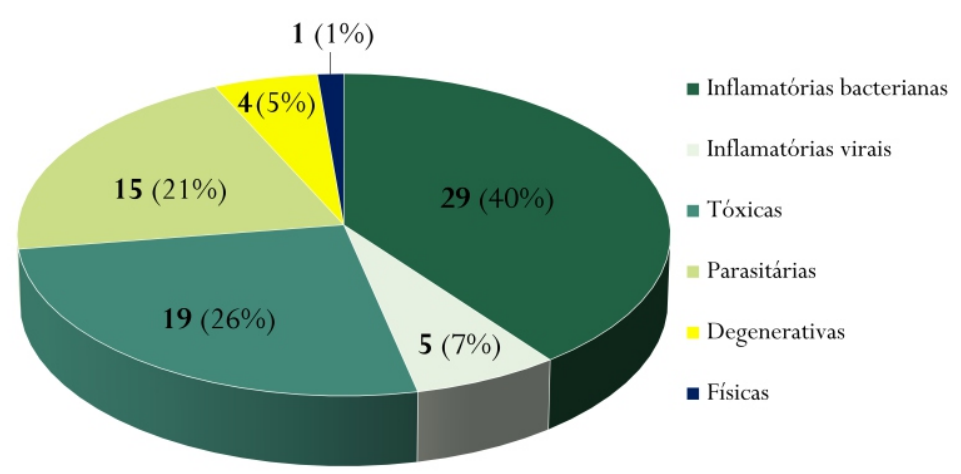

Figura 15. Causas de doenças neurológicas em ovinos. Reunião dos estudos de casuística realizados nos estados da $\mathrm{PB}^{10}$ e do $\mathrm{RS}^{11}$.

lites e mielites, realizado no RS com as três espécies ruminantes, as doenças causadas por bactérias acometeram somente $13 \%$ (28/219) dos bovinos portadores de inflamação no SNC. Por outro lado, ocorram em 90\% (19/21) dos ovinos e em 100\% (7/7) dos caprinos, com destaque para a listeriose. Esta doença acometeu somente $1,8 \%(4 / 219)$ dos bovinos, mas foi muito frequente em ovinos $(38 \%$; 8/21) e em caprinos $(71 \%$; $5 / 7)^{3}$.Isto prova que a listeriose é pouco importante em bovinos no Brasil, mas possui relevância epidemiológica destacada nos pequenos ruminantes. A primeira causa importante neste grupo de enfermidades nos ovinos são os abscessos localizados no $\mathrm{SNC}$ e a raiva é a única encefalite viral diagnosticada (Quadro 7).

As causas tóxicas são primariamente representadas pelo tétano (13,7\% dos casos) e pelas intoxicações com plantas com ação direta sobre o SNC ou hepatotóxicas, provocando encefalopatia hepática $(10,9 \%$ dos casos). E a única causa parasitária é a cenurose, forma larvar da Taenia multiceps, denominada Coenurus cerebralis, cujo cisto se desenvolve dentro o encéfalo, expandindo-se, ocupando espaço e comprimindo as estrutu-

Quadro 7.Principais doenças neurológicas em ovinos apresentadas por ordem decrescente de ocorrência. Reunião dos estudos de casuística realizados nos estados da $\mathrm{PB}^{10}$ e do $\mathrm{RS}^{11}$.

22,0 Abscessos no SNC (encéfalo ou medula) ou no canal vertebral

2

3

3

4

5

6

7

8

8

8
20,5 Cenurose

13,7 Listeriose

13,7 Tétano

10,9 Intoxicação com plantas com ação direta sobre o SNC ou hepatotóxicas

6,8 Raiva

5,4 Polioencefalomalacia

2,7 Mielite bacteriana ascendente (pós-caudectomia)

1,3 Meningoencefalite bacteriana (não organizada em abscesso)

1,3 Traumatismos no crânio ou na coluna vertebral

1,3 Necrose simétrica focal 
ras. Esta enfermidade apresenta frequência muito elevada (20,5\% dos casos), porém está superestimada devido à prevalência alta no $\mathrm{RS}^{11}$. O cão é o hospedeiro definitivo da tênia e o convívio direto com os ovinos nas áreas de pastagem é o fator de risco primordial. A doença somente ocorre em locais em que os cães são usados como pastores dos ovinos. Portanto, tem relevância epidemiológica na região Sul do país, notadamente o RS. Provavelmente não ocorra nas demais regiões. Por fim, a PEM também ocorre em ovinos com frequência equivalente a 5,4\% dos casos.

$\mathrm{Na}$ casuística de doenças neurológicas em ovinos atendidos no serviço de clínica médica de grandes animais do Hospital Veterinário da Universidade Estadual de Londrina (HOVET/UEL), nos últimos 26 anos, destacaram-se o tétano $(44,4 \%)$ e a mielite bacteriana ascendente pós-caudectomia (16,7\%). Muitos destes casos de tétano ocorreram também após caudectomia, particularmente quando se adotava o procedimento de garroteamento com anel de borracha elástica. A amputação da cauda caiu em desuso no $\mathrm{PR}$, a mielite ascendente reduziu-se quase a zero e o tétano tornou-se mais esporádico. Outras doenças diagnosticadas foram meningoencefalite bacteriana $(8,3 \%)$, toxemia da prenhez $(8,3 \%)$, intoxicação por ureia (amônia) (8,3\%), intoxicação com plantas hepatotóxicas e encefalopatia hepática (5,5\%), listeriose, PEM e abscessos no SNC (2,8\% cada).

O único estudo de casuística sobre as doenças neurológicas em caprinos que seja do conhecimento dos autores da presente revisão foi realizado no semiárido da região Nordeste, principalmente no Estado da $\mathrm{PB}^{10}$. Dois outros estudos realizados no RS também forneceram informações, mas incluíram número muito reduzido de animais ${ }^{3,12}$. Portanto, as observações de doenças diagnosticadas no Brasil podem ser consideradas escassas para esta espécie.

Nos dois estudos do RS, a listeriose foi a doença de maior importância. No semiárido nordestino destacaram-se tétano (23,4\% dos casos), raiva, abscessos no SNC, listeriose, intoxicação com plantas com ação direta sobre o SNC e traumatismos do crânio ou da coluna vertebral (8,8\% dos casos cada), ataxia enzoótica, toxe- mia da prenhez e meningite (5,9\% dos casos). A PEM também foi observada (2,9\% dos casos).

No atendimento de clínica médica de grandes animais do HOVET/UEL, as doenças neurológicas de caprinos ocorreram em número reduzido e foram diagnosticados; tétano $(26,7 \%)$, meningoencefalite bacteriana (20\%), intoxicação com plantas com ação direta sobre o SNC (20\%), encefalite por lentivírus de pequenos ruminantes em cabritos (13,3\%), PEM (13,3\%) e hipoglicemia (6,7\%).

É necessário que o leitor seja alertado sobre determinadas doenças neurológicas dos ruminantes que certamente ficaram com ocorrências subestimadas nos levantamentos apresentados. É o caso das doenças metabólicas e das doenças congênitas. As doenças metabólicas que determinam disfunção neurológica e ocorrem no Brasil são a paresia puerperal hipocalcêmica $(\mathrm{PPH})$ na vaca, a toxemia da prenhez e a hipocalcemia na ovelha e na cabra em final de gestação, a forma nervosa da cetose na vaca em início de lactação e a hipoglicemia/hipotermia nos cordeiros e cabritos neonatos. $\mathrm{O}$ clínico buiatra cuja rotina é voltada para os bovinos leiteiros pode se deparar frequentemente com $\mathrm{PPH}$ e cetose, presumir o diagnóstico e confirmá-lo com a resposta ao tratamento. Por este motivo, os casos não aparecem nos levantamentos de casuística apresentados. Além disso, os bovinos de corte representaram o maior contingente de ocorrências nos cinco principais estudos de casuística agrupados nesta revisão. É natural, portanto, que doenças que afetam especificamente vacas leiteiras, acabassem com ocorrência subestimada.

É coerente admitir, também, que os casos de toxemia da prenhez ou de hipocalcemia em ovelhas e cabras gestantes possam ter sido computados como doença metabólica e ficado de fora da casuística de doenças neurológicas nos levantamentos. Em muitos destes animais a diminuição do nível de consciência é profunda e caracteriza, obviamente, disfunção cerebral.

Quanto aos neonatos, e particularmente os perinatos, que apresentam distúrbios neurológicos, é compreensível que o produtor os considere animais não viáveis e decidam abreviar-lhes a vida sem solicitarem o serviço veterinário para esclarecimento do diagnóstico. 


\section{SÍNDROMES NEUROLÓGICAS OBSERVADAS NAS PRINCIPAIS DOENÇAS}

\section{- Diagnóstico diferencial preliminar aplicado}

O tétano é a única doença neurológica certamente passível de diagnóstico clínico, uma vez que possui manifestações características: rigidez muscular generalizada (membros, pescoço e cabeça) e hiperestesia. A excitação pode ocorrer, mas não há outros sinais de síndrome cerebral e animais com quadros avançados podem apresentar grave rigidez muscular (Figura 16). A exposição da terceira pálpebra, comum nos equinos, nem sempre está presente nos ruminantes.

Poucas doenças além do tétano podem ser diagnosticadas com base em critérios puramente clínicos.

O trauma craniano é acompanhado por síndrome cerebral aguda devido à ocorrência de edema cerebral difuso e deve ser diferenciado de outras enfermida-

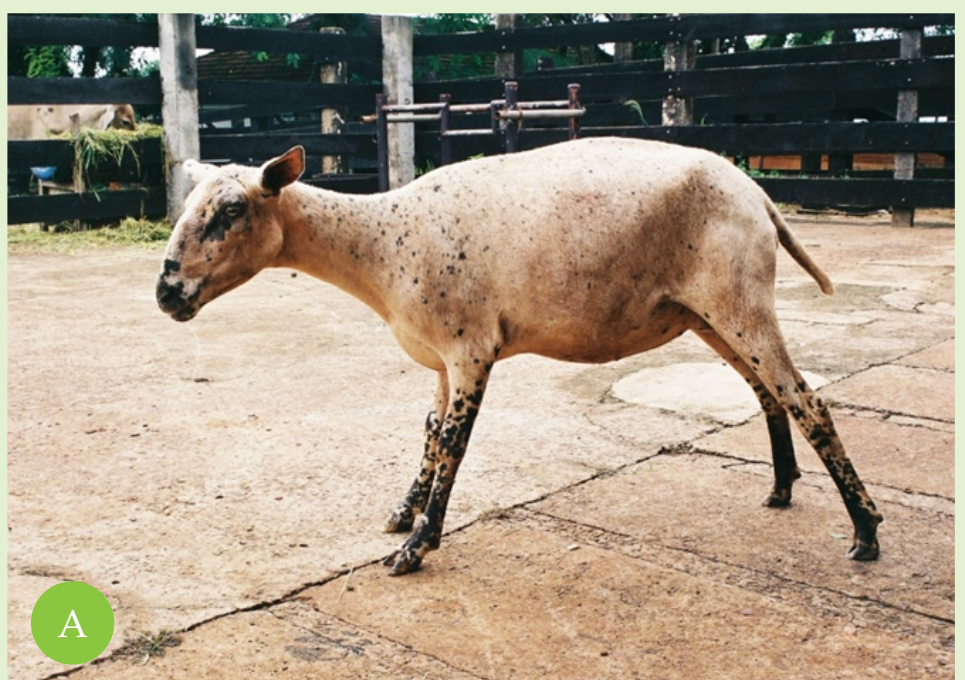

des que cursam com estas manifestações. Porém, pode ser assumido como diagnóstico definitivo se houver o relato da ocorrência pela pessoa que assistiu e/ou se houver lesões aparentes no crânio.

O mesmo se aplica aos traumatismos da coluna vertebral que provocam síndromes medulares caracterizadas por incoordenação motora (ataxia e/ou paresia) devido à compressão da medula espinhal. $\mathrm{O}$ relato da ocorrência, o curso agudo e evidências de alterações ósseas (desvios, desalinhamentos e/ou mobilidade anormal e crepitação das vértebras) são elementos que garantem o diagnóstico.

Quadros de intoxicação por organofosforados, carbamatos e ureia (amônia) caracterizam-se por aparecimento súbito de excitação, tremores musculares generalizados, sialorreia, incoordenação motora (ataxia) e convulsão; e diarreia, miose e bradicardia no caso dos organofosforados. Podem ser assumidos como diagnóstico definido se houver a informação segura de ingestão (ureia) ou de exposição (organofosforados e carbamato) prévia recente.

Afora estas situações específicas, o que ocorre

Figura 16. (A) Ovelha com tétano em fase inicial da evolução apresentando rigidez muscular nos membros e no pescoço, orelhas eretas, cauda ereta (em bandeira), posição em cavalete com base ampla de apoio (membros torácicos projetados para frente e membros pélvicos projetados para trás), dificuldade de locomoção com marcha rígida (pouca ou nenhuma flexão das articulações dos membros) e grau leve de hiperestesia, caso isolado no rebanho. (B) Garrote acometido por polioencefalomalacia apresentando decúbito permanente, espasticidade dos membros, opistótono, depressão (resposta diminuída aos estímulos do meio) alternando com episódios de hiperestesia em grau leve e amaurose bilateral, caso isolado no rebanho. O garrote havia sido castrado há dez dias. Entretanto, não se pode confundir com o tétano devido à presença de sinais de síndrome cerebral, notada-

mente a amaurose.

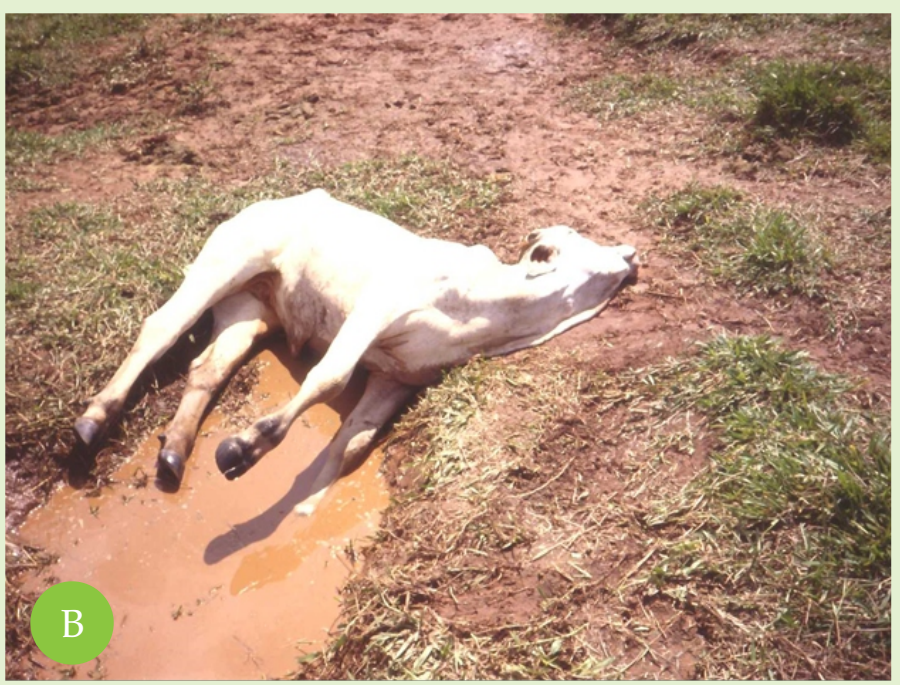


mais comumente é que as doenças se confundem entre si e estabelecer o diagnóstico diferencial é o desafio obrigatório. Nos ruminantes, as encefalopatias são numerosas e podem ocorrer na forma de surtos, ao passo que as mielopatias são pouco frequentes e costumam acometer indivíduos isoladamente. É importante reforçar um conceito: a primeira discriminação que o clínico deve realizar ao iniciar o exame físico de um animal exibindo disfunções neurológicas é se ele apresenta encefalopatia ou mielopatia. No primeiro caso, haverá sinais de síndromes cerebral, cerebelar, mesencefálica ou pontinobulbar, associadas ou não entre si. No segundo caso, haverá exclusivamente incoordenação motora (ataxia e/ou paresia) em graus variados, sem alterações da consciência, do comportamento e da personalidade (Figura 17). Na maioria das doenças apre-
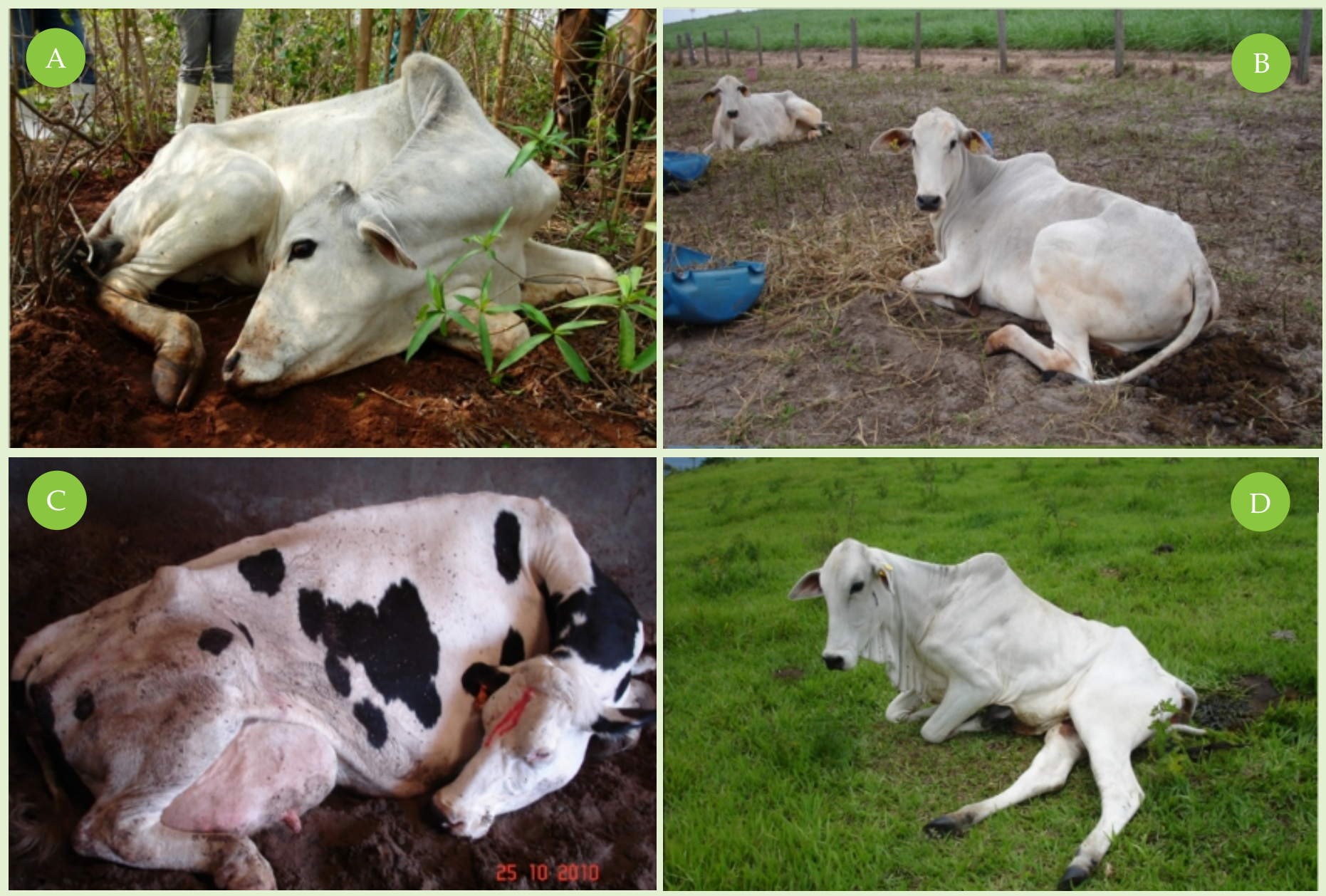

Figura 17. Bovinos apresentando fraqueza muscular (paresia) e decúbito permanente devido à incapacidade de se erguer, sustentar o peso e caminhar por causas diversas. (A) Garrote intoxicado por Acanthocladus brasiliensis em um surto. (B) Vacas intoxicadas por Senna obtusifolia em um surto. (C) Vaca recém-parida acometida por paresia puerperal hipocalcêmica; caso isolado. (D) Novilha acometida por botulismo em fase inicial da evolução, caso isolado. Notar que alguns bovinos apresentam alteração da consciência (depressão) e nestes casos deve-se suspeitar das doenças que causam encefalopatia, principalmente com disfunção do córtex cerebral e/ou do mesencéfalo (A e C). Nos bovinos que apresentam resposta normal aos estímulos do meio (B e D) devem-se considerar as hipóteses de disfunção da medula espinhal (mieloptias), da placa motora, da musculatura dos membros (miopatias) e de ossos e articulações dos membros. Lembrar que em alguns casos de raiva pode haver paresia devido à mielite sem sinais de encefalopatia no início da evolução, os quais estarão obrigatoriamente presentes e evidentes nos dias seguintes antecedendo a morte. Apesar de a toxina botulínica agir na placa motora e não no SNC, bovinos com botulismo apresentarão diminuição do grau de consciência (depressão) com a evolução do quadro. Algumas das vacas intoxicadas por Senna obtusifolia apresentaram depressão devido à encefalopatia hepática decorrente de necrose hepática. 
sentadas nos Quadros 6 e 7 há lesão e/ou disfunção de estruturas do encéfalo.

Tomando como base as síndromes neurológicas e a evolução, serão apresentadas a seguir as manifestações esperadas em cada enfermidade relevante. É necessário salientar, contudo, que sempre haverá possibilidade de variações e exceções à regra. A síndrome cerebral de evolução aguda, acompanhada ou não por sinais das demais síndromes encefálicas, é o padrão das seguintes doenças: meningoencefalite por BoHV- $5^{18-21}$,
$\mathrm{PEM}^{22-25}$, babesiose cerebral ${ }^{26-28}, \mathrm{FCM}^{29-33}$, trauma cranioencefálico, intoxicação por chumbo, intoxicação por $\mathrm{NaCl}^{9}$, histofilose ${ }^{34}$ e encefalopatia hepática devido à intoxicação com plantas que determinam necrose aguda no fígado ${ }^{15,35}$. Também pode ocorrer nos casos de meningoencefalite bacteriana não organizada. Os sinais de disfunção são evidentes e acentuados desde o início porque em muitas destas enfermidades existe edema cerebral difuso (Figura 18).

A manifestação dos sinais de síndrome cerebe-
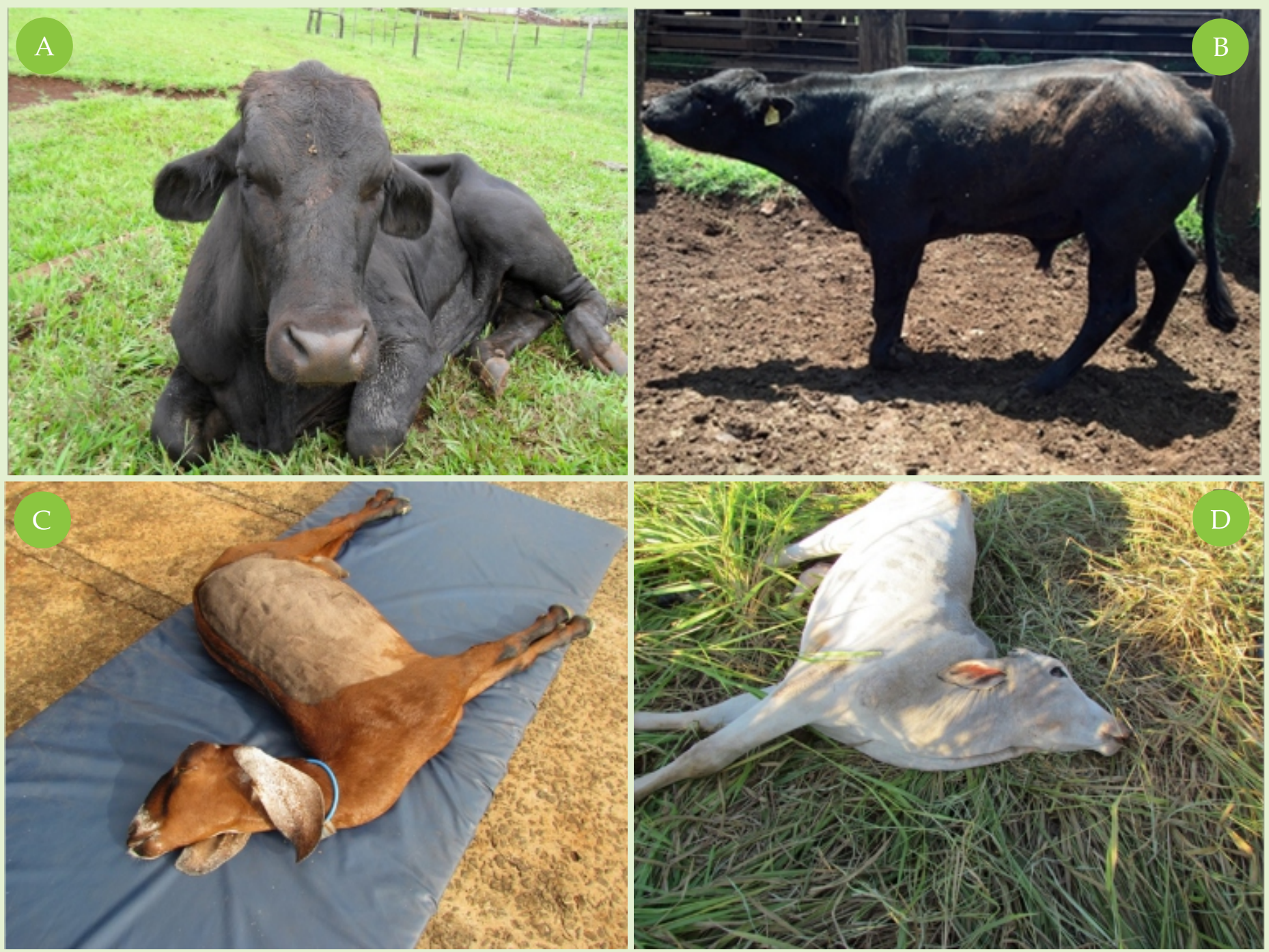

Figura 18. Doenças neurológicas com manifestação de sinais de síndrome cerebral aguda. (A) Bezerro com meningoencefalite por BoHV-5 apresentando depressão, amaurose, movimentos repetidos e involuntários da cabeça e da orelha direita e decúbito permanente, 96 horas de evolução, ocorrência em surto. (B) Bezerro com babesiose cerebral apresentando excitação, tremores musculares generalizados, rigidez da musculatura cervical com extensão de pescoço e cabeça e déficit proprioceptivo, evoluindo para convulsão, oito horas de evolução, caso isolado. (C) Cabra com meningoencefalite bacteriana apresentando depressão, amaurose, midríase, opistótono, rigidez dos membros e decúbito permanente, 24 horas de evolução, caso isolado. (D) Garrote com intoxicação por $\mathrm{NaCl}$ e privação de água demonstrando depressão, amaurose, estrabismo dorsomedial, opistótono, grau leve de hiperestesia com episódios de hipextensão e rigidez dos membros e decúbito permanente, 36 horas de evolução, ocorrência em surto. 
lar e de síndromes mesencefálica e pontinobulbar pode dever-se à presença de lesões localizadas nestas estruturas (cerebelo e tronco encefálico), ou à compressão consequente ao aumento da pressão intracraniana. Nesta última situação, a redução do edema cerebral resultará em amenização ou desaparecimento dos sinais.

Sinais de excitação (atividade neuronal exagerada) e/ou de deficiência (atividade neuronal diminuída) estarão presentes nestas doenças e podem variar em intensidade ao longo da evolução. Os sinais de excitação, incluindo a possibilidade de convulsão, e a evolução curta até a morte ( 12 a 36 horas) predominam nos casos de babesiose cerebral ${ }^{26-28}$ e de encefalopatia hepática devido à intoxicação com plantas que determinam necrose aguda no fígado ${ }^{15,35}$. Os sinais de depressão são mais comuns na meningoencefalite por $\mathrm{BoHV}-5^{18-21}$, na $\mathrm{FCM}^{29-33}$ e na histofilose ${ }^{34}$. Nos casos de $\mathrm{PEM}^{22-25}$, trauma cranioencefálico, intoxicação por chumbo e intoxicação por $\mathrm{NaCl}$, sinais de excitação podem predominar no início da evolução (Figuras 16 e 18). Nestas doenças, a morte poderá ocorrer entre dois e seis dias de evolução.

No caso dos abscessos localizados no encéfalo, assim como na cenurose, os sinais de disfunção podem ser menos agudos do que os apontados nas doenças anteriores, discretos no início e se agravarem com o tempo.Isto explica o tempo de evolução maior.

As lesões clássicas na listeriose (microabscessos ou granulomas) localizam-se no troncoencefálico determinando os sinais predominantes de síndrome pontinobulbar e/ou mesencefálica, notadamente disfunções assimétricas (unilaterais) dos nervos cranianos. Menos frequentemente poderá haver sinais de síndrome cerebral aguda ${ }^{13}$ devido à presença de lesões multifocais no encéfalo. Portanto, com base nos sinais mais comumente exibidos, a listeriose poderia ser diferenciada, com certa facilidade, das demais enfermidades citadas anteriormente.

Os quadros de encefalopatia hepática devido à intoxicação com plantas hepatotóxicas que determinam lesão crônica no fígado (cirrose hepática) são diferentes daqueles mencionados anteriormente com a lesão hepática aguda que provocam a morte rápida. Os sinais de síndrome cerebral podem aparecer subitamente, mas possuem magnitude menos acentuada e o tempo de evolução até a morte é maior. Alterações do comportamento como manias ou atos bizarros e compulsivos são frequentemente observados, mas a depressão (diminuição das respostas aos estímulos do meio) também é comum. Outros sinais costumam estar presentes e antecedem o aparecimento das disfunções neurológicas, tais como emagrecimento progressivo, dilatação do abdômen devido à ascite e diarreia crônica ${ }^{15}$, embora a icterícia seja encontrada raramente. Distintamente da necrose hepática aguda, a cirrose hepática nem sempre provoca encefalopatia hepática. Assim sendo, em uma situação de surto em um rebanho, alguns animais apresentarão sinais de síndrome cerebral e outros não.

Os animais intoxicados por plantas com ação direta sobre o SNC que provocam doenças do armazenamento apresentam, de forma geral, sinais de síndrome cerebelar ${ }^{15,16}$. Tremores musculares localizados ou generalizados com ou sem incoordenação motora (ataxia) são as manifestações relacionadas à ingestão de plantas que causam síndrome tremorgênica e de plantas que albergam fungos produtores de determinadas toxinas. Em ambos os casos, a córtex cerebral não costuma ser afetada e não se observam alterações do comportamento e da personalidade.

A presença de outros sintomas concomitantes aos distúrbios neurológicos também pode auxiliar o clínico na tarefa de diferenciação das enfermidades. Bovinos com meningoencefalite herpética (infecções por BoHV-5 ou BoHV-1) podem apresentar sinais de inflamação das vias aéreas craniais (secreção nasal bilateral, estridores respiratórios, tosse) e, raramente, pneumonia. Na maioria dos casos, contudo, somente os sinais de síndromes encefálicas estão presentes ${ }^{18-21} . \mathrm{Na}$ histofilose o mesmo pode acontecer ${ }^{34}$. Finalmente, bovinos acometidos por FCM podem apresentar variedade de manifestações digestórias (estomatite, ulcerações na boca, diarreia), respiratórias (secreção nasal bilateral, tosse, dispneia), oculares (ceratite com opacidade e úlcera de córnea, hipópio, conjuntivite, secreção ocular, diminuição de acuidade visual) e cutâneas (der- 
matite crostosa de extensão variável, ressecamento e descamação da mufla e das narinas), desidratação e emagrecimento ${ }^{29-33}$. Em um surto da doença, nem todos os bovinos apresentarão sinais de distúrbio neurológico. $\mathrm{Na}$ experiência do $\mathrm{PR}$, a doença ocorreu como casos isolados no rebanho e os bovinos apresentaram exclusivamente sinais neurológicos".

A raiva é uma doença que leva à morte em até cinco dias, na maioria dos casos. Alguns, entretanto, podem ter duração mais prolongada usualmente de até dez dias, porém como exceção casos com até dezesseis dias de evolução já foram observados. A raiva confunde-se com qualquer uma das doenças neurológicas anteriormente mencionadas ${ }^{36-38}$, assim como, com o botulismo, descrito a seguir. Animais raivosos podem apresentar sinais de encefalopatia desde o início da evolução e nestes casos a morte é rápida. Com este padrão de evolução a raiva deve ser diferenciada de todas as doenças que cursam com síndrome cerebral aguda (Figura 19).
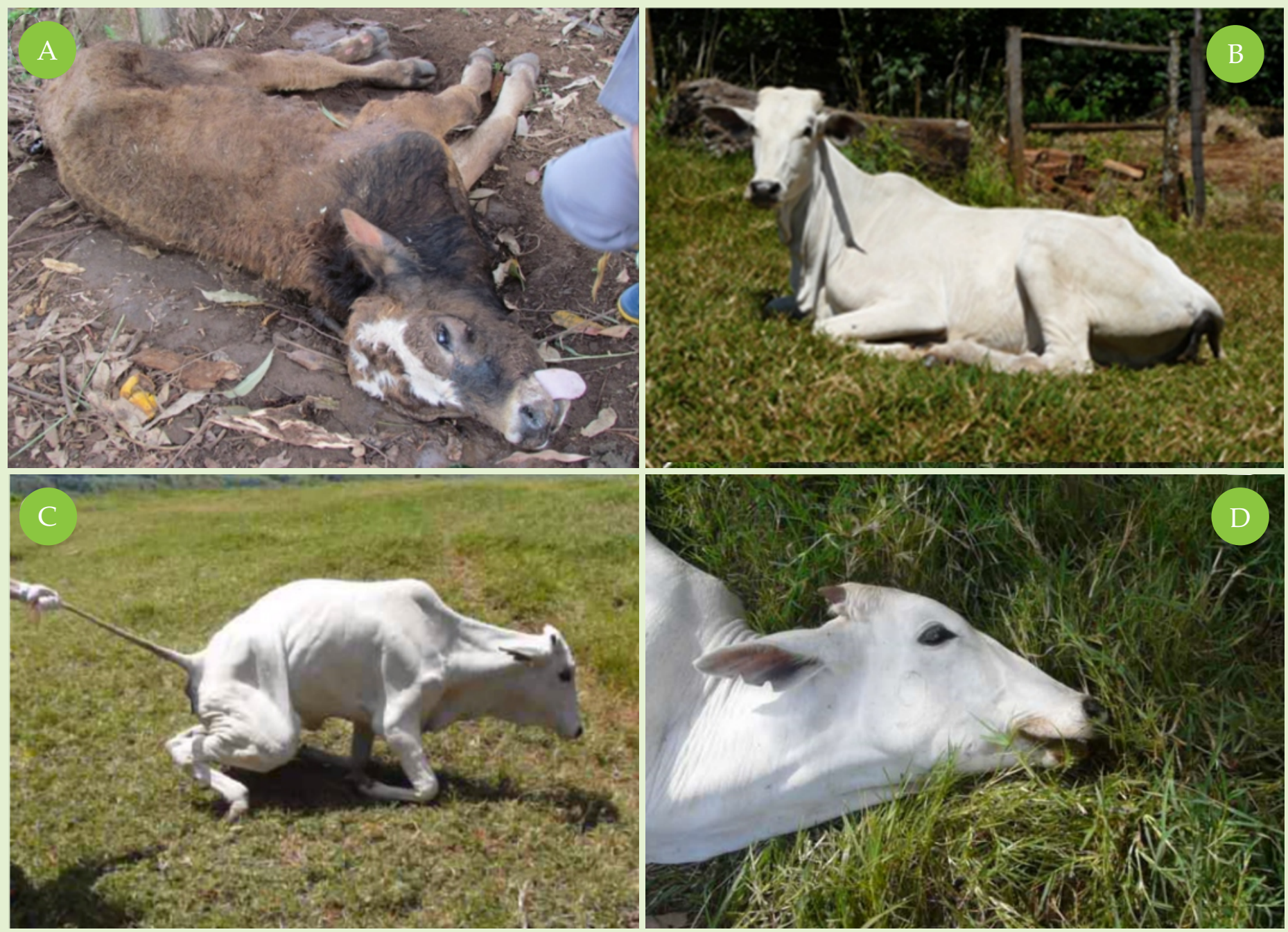

Figura 19. Bovinos com raiva. (A) Sinais de encefalopatia podem estar presentes desde o início do quadro, confundindo-se com as demais doenças que causam síndrome cerebral aguda, ou podem aparecer somente no final da evolução (B, C e D), confundindo-se com o botulismo. (A) Bezerro apresentando amaurose bilateral, depressão, nistagmo, flacidez da língua e tetraparesia com decúbito lateral permanente, quadro com sessenta horas de evolução e ocorrência em surto no rebanho. A língua não estava exposta originalmente, mas permaneceu após a tração manual. (B) Novilha em decúbito esternal permanente há 48 horas, mantendo-se alerta e sem outros sinais de encefalopatia desde o início da evolução, caso isolado. (C) Novilha sendo estimulada e realizando tentativas de se erguer, sem sucesso, demonstrando paresia mais acentuada nos membros pélvicos. (D) Decúbito lateral permanente e depressão, após dois dias de evolução. 
Porém, os animais acometidos podem iniciar o quadro com sinais exclusivos de síndromes medulares, apresentando paraparesia que evolui para tetraparesia. Nestes casos, podem ser capazes de se erguer e caminhar com fraqueza muscular mais evidente nos membros pélvicos (paraparesia). Com a evolução para tetraparesia adotam decúbito esternal permanente. Sinais de síndromes encefálicas aparecerão na sequência, obrigatoriamente, antecedendo a morte (Figura 19).É possível, portanto, que o animal raivoso permaneça em decúbito esternal por poucos dias sem manifestar sinais aparentes de encefalopatia. Com este padrão de evolução, a raiva deve ser diferenciada das mielopatias de forma geral, das doenças musculares com lesões extensas, como nos casos de intoxicação por Senna occidentalis e por Senna obtusifolia em bovinos, e do botulismo. Esta diversidade de padrões de evolução na raiva se deve ao tipo de trajeto do vírus rábico dentro do SNC e à sua velocidade, provocando mielite e disfunções medulares antes da encefalite que culminará na morte ${ }^{36,38}$. Sinais não usuais em pacientes com raiva já foram observados pelos autores, como por exemplo intenso prurido. Neste bovino, sinais cerebrais só foram obser- vados depois de quatro dias de evolução e a raiva foi confirmada laboratorialmente, mas a EEB e a doença de Aujesky foram também considerados diagnósticos diferenciais (não confirmados posteriormente).

Quando é possível acompanhar a evolução, não é difícil distinguir a raiva das mielopatias e das miopatias uma vez que a morte não ocorre rapidamente nestas enfermidades. Com respeito ao botulismo, contudo, pode ser difícil diferenciar as duas enfermidades. Ambas as doenças, raiva e botulismo, são fatais e o tempo de evolução até a morte é parecido, até sete dias. Casos muito raros de botulismo em bovinos podem ter evolução crônica e retorno à saúde. No botulismo a fraqueza muscular generalizada leva ao decúbito esternal permanente. No início do quadro o bovino é alerta e não apresenta sinais de encefalopatia. Com a evolução, torna-se deprimido e evolui para decúbito lateral antes da morte $^{39}$ (Figura 20).

A causa da depressão no botulismo é incerta visto que os receptores para a toxina botulínica estão na junção neuromuscular e não no sistema nervoso central. Além da depressão e da flacidez da língua, que pode estar ou não presente, não há outros sinais de ence-
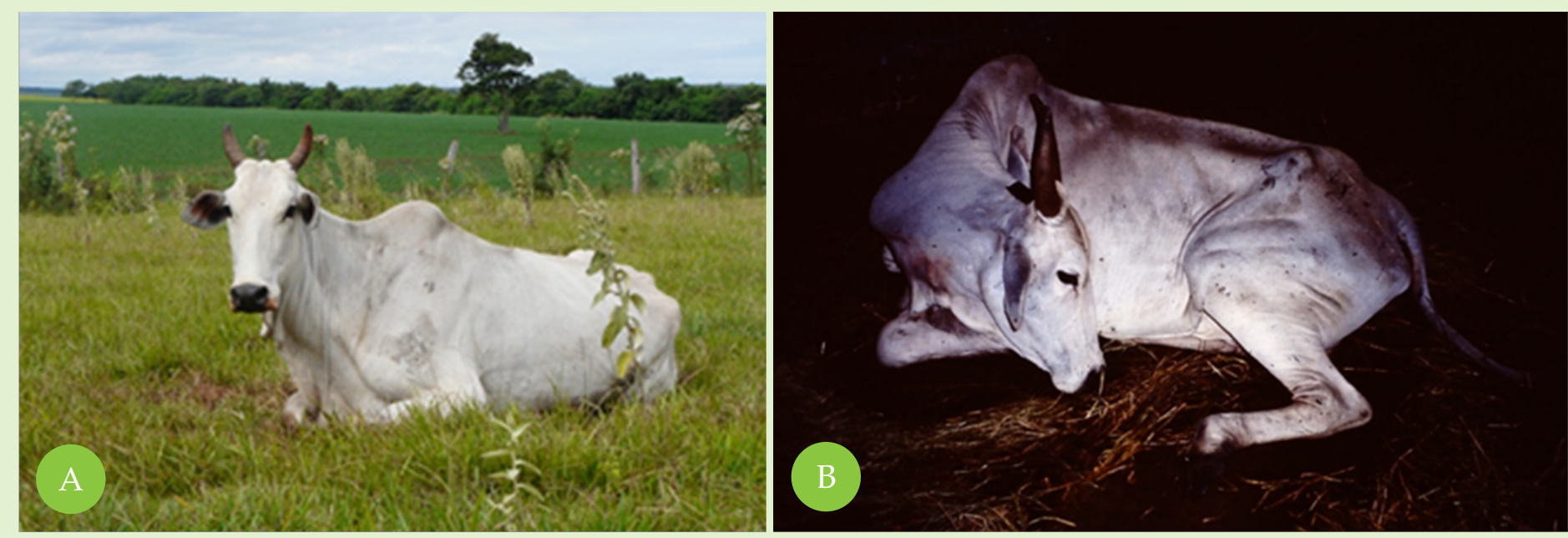

Figura 20. Vacas acometidas por botulismo. A fraqueza muscular generalizada com decúbito permanente é o padrão desde o início do quadro. A diminuição do grau de consciência (depressão) não está presente no início (A), mas aparece durante a evolução (B). Não há outros sinais de encefalopatia presentes, tais como cegueira, excitação, manias, tremores musculares, e a flacidez da língua nem sempre ocorre. Este é o padrão esperado na evolução desta enfermidade e a informação sobre como era o comportamento no início do quadro é fundamental para o raciocínio clínico. Bovinos que apresentam alteração da consciência ou outros sinais de encefalopatia desde o início muito provavelmente não estão acometidos por botulismo. Importante reforçar que alguns casos de raiva podem apresentar este mesmo padrão de evolução. 
falopatia no botulismo. Isto efetivamente o diferencia das demais doenças do encéfalo e da própria raiva, quando sinais variados de síndromes encefálicas estão presentes (Figura 19A). Deve-se reforçar este conceito muito importante: botulismo pode se confundir com alguns casos de raiva (Figura 19B e C), com casos de mielopatia e com casos de miopatia acentuada e de distribuição extensa (Figura 17B). Botulismo, por outro lado, jamais deve ser confundido com as enfermidades que cursam com síndrome cerebral aguda tais como meningoencefalite por BoHV-5, PEM, babesiose cerebral, FCM, trauma cranioencefálico, intoxicação por chumbo, intoxicação por $\mathrm{NaCl}$, histofilose e encefalopatia hepática (Figuras 16B e 18).

É preciso ressaltar que existem muitos outros trabalhos publicados sobre enfermidades neurológicas no Brasil, abordando problemas específicos como por exemplo scrapie em ovinos ou relatos de intoxicações, que apesar de serem importantes contribuições, não foram citados nesta revisão, mas que constituem importante fonte de consulta para abordagem de anormalidades neurológicas.

\section{- Métodos que reforçam suspeitas ou que confirmam diagnóstico antes da morte}

Alguns exames laboratoriais auxiliam no diagnóstico diferencial entre as doenças neurológicas antes da morte. No líquido cefalorraquidiano (LCR), a presença de pleiocitose (aumento do número de leucócitos $>8$ células $/ \mathrm{mm}^{3}$ ) e a hiperproteinorraquia (aumento da concentração de proteínas $>40 \mathrm{mg} / \mathrm{dL}$ ) confirmam a existência dos processos inflamatórios no encéfalo ou na medula ${ }^{40,41}$. A ausência de alterações não descarta completamente, contudo, a suspeita de encefalite. Alguns bovinos com raiva e com histofilose podem apresentar LCR sem alterações ${ }^{42,43}$. $\mathrm{Na}$ encefalite por BoHV-5, por outro lado, a pleiocitose com células mononucleres (linfócitos e macrófagos) está sempre presente e pode ser acentuada ( $>50$ células $\left./ \mathrm{mm}^{3}\right)^{42,44}$. Nos casos de encefalite e de mielite bacterianas, a hiperproteinorraquia costuma ser muito acentuada e a pleiocitose com neutrófilos é a alteração marcante. Além das alterações celulares e bioquímicas mencionadas, a elevação da concentração de lactato no LCR ( $>3,6 \mathrm{mmol} / \mathrm{L})$ é um indicador confiável de encefalite em bovinos ${ }^{43}$.

As alterações presentes no LCR não confirmam diagnóstico, mas confirmam que existe inflamação e indicam qual é o provável agente causador: vírus ou bactéria. Isto, por si só, já representa um enorme passo para a diferenciação preliminar entre as enfermidades. A presença de hemácias crenadas, por sua vez, indica a existência de hemorragia prévia e reforça a suspeita de lesões traumáticas na coluna vertebral ou no crânio. Finalmente, concentrações de sódio muito altas (podendo chegar a até $200 \mathrm{mmol} / \mathrm{L}$ ) no LCR de bovinos confirmam o diagnóstico de intoxicação por $\mathrm{NaCl}$ associada à privação de água ${ }^{45}$.

O diagnóstico das doenças hepáticas que determinam encefalopatia hepática pode ser reforçado com a constatação de aumento das atividades das enzimas gamaglutamil transferase (GGT) e aspartato aminotransferase (AST) e da concentração de bilirrubinas no soro sanguíneo. No caso das doenças musculares, a elevação da atividade da enzima creatinoquinase $(\mathrm{CK})$ no soro sanguíneo confirma a presença da lesão muscular e os valores são muito elevados (>10.000 UI/L) nas intoxicações por Senna obtusifolia ${ }^{17}$, sendo que a mioglobinúria (urina com coloração enegrecida) também é uma manifestação comum nesta enfermidade. A atividade da CK também se eleva em bovinos ou bubalinos pesados que permanecem em decúbito por tempo prolongado, o que pode acontecer em várias doenças neurológicas. Isto ocorre devido à lesão muscular decorrente da compressão, diminuição da perfusão sanguínea e hipóxia tecidual. Nestes casos, geralmente, a mioglobinúria não está presente e a elevação da atividade sérica da CK é menos acentuada.

Finalmente, o diagnóstico terapêutico é possível na PEM por alteração no metabolismo tiamina, quando se observa resposta efetiva e rápida à administração de tiamina (vitamina B1) ${ }^{23}$. Nem todos os rumi- 
nantes acometidos por PEM respondem ao tratamento, contudo, a ausência de resposta não descarta a doença. Como regra válida para as doenças neurológicas de forma geral, a resposta ao tratamento é melhor quando é instituído o mais rapidamente possível após o aparecimento dos sinais de disfunção (início da evolução). A tiamina deve ser administrada, por via intramuscular, em dose de 10 a $20 \mathrm{mg} / \mathrm{kg}$, a cada oito ou doze horas nos primeiros dois dias e a cada 24 horas por mais dois ou três dias, de acordo com a necessidade ${ }^{23,45}$. Doses maiores do que estas podem ser utilizadas no primeiro dia e a melhora clínica pode já ser observada poucas horas após a administração. Os casos de PEM, por excesso de enxofre, não respondem adequadamente a este tipo de tratamento. De acordo com a experiência prática dos autores, bovinos acometidos por meningoencefalite por BoHV-5 e ruminantes com trauma cranioencefálico também podem responder ao tratamento com tiamina. No entanto, a magnitude e a rapidez da melhora clínica são menores quando comparadas ao que ocorre na PEM. Nos casos mais avançados de PEM a resposta ao tratamento com tiamina pode ocorrer desta forma ou não ocorrer.

Quando abordamos os diagnósticos diferenciais, podemos citar muitos outros que podem, dependendo da situação ou disponibilidade, serem utilizados. Exemplos disto são: a determinação de $\mathrm{H}^{2} \mathrm{~S}$ ruminal e casos de PEM por excesso de enxofre, raio X em lesões traumáticas ou empiema vertebral em bovinos, tomografia computadorizada para lesões em coluna vertebral, ressonância magnética em enfermidades encefálicas, utilização de técnicas de PCR no sangue ou LCR para confirmar a presença de agentes patogênicos, determinação de metais pesados ou produtos tóxicos no soro, plasma ou sangue total e uso de técnicas de eletroneurodiagnóstico. A maioria delas utilizadas em centros de diagnóstico e não disponíveis para utilização a campo.

\section{CONSIDERAÇÕES FINAIS}

Diante do exposto, é possível destacar que, apesar das doenças neurológicas confundirem-se entre si,o clínico buiatra é capaz de realizar a tarefa de discriminação entre elas, com certo êxito, tomando como base critérios clínicos e algumas informações laboratoriais específicas. O reconhecimento das síndromes neurológicas presentes e a interpretação correta dos sinais correlacionando-os com a localização provável das lesões ou disfunções nas estruturas do SNC são os fundamentos para que possa elaborar uma lista preliminar de suspeitas coerente, racional e o mais reduzida possível. Os resultados de alguns exames laboratoriais, destacando-se a importância das alterações presentes no LCR, podem auxiliar decisivamente o diagnóstico diferencial das doenças neurológicas dos ruminantes antes da morte. A fase seguinte nos animais sacrificados ou que vierem a óbito deve contar com o envio de amostras de locais específicos do sistema nervoso obtidas durante a necropsia e encaminhadas ao patologista pois possuem grande valor diagnóstico para a implementação de medidas terapêuticas e profiláticas no rebanho. 


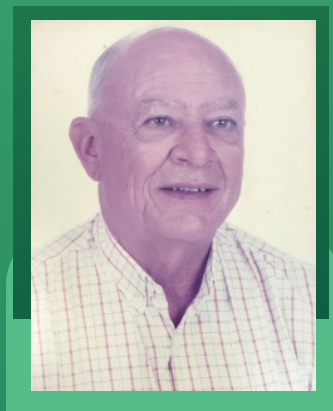

Os autores desta revisão, especialmente J.A.N. Lisbôa e A.S. Borges, na qualidade de exresidentes e ex-orientados de pósgraduação, aproveitam a oportunidade para agradecer e prestar homenagem justificada ao Prof. Dr. Marcio Rubens Graf Kuchembuck. O Dr. Marcio, professor de Clínica Médica de Grandes Animais, desenvolveu a sua carreira na FMVZ, UNESP, Campus de Botucatu, e foi, muito provavelmente, o primeiro clínico brasileiro a aprofundar os conhecimentos sobre neurologia em animais de grande porte. Em 1977, defendeu a sua tese de doutoramento, na Universidade de Minnesota, EUA, com trabalho de indução experimental de listeriose em bovinos. Há exatos quarenta anos publicou junto com Prof. Dr. Luiz Nicoletti da FMVZ - Botucatu, a apostila intitulada "Exame Neu- rológico dos Animais Domésticos”. Somos muito gratos de termos tido a oportunidade de desfrutar do convívio e ensinamentos do Dr. Marcio que transmitia seus ensinamentos com entusiasmo, paixão, clareza, raciocínio lógico e criticismo impressionantes, conseguindo, desta forma, influenciar muitos profissionais que estiveram sob a sua orientação a também se interessarem, de maneira profunda, pelas doenças neurológicas. Este é o legado de um grande mestre. Desfrute a paz merecida.

Por fim, os autores desejam agradecer a todos os pesquisadores brasileiros que dedicam parte dos seus esforços de investigação científica a este campo tão fascinante e desafiador que abrange as doenças neurológicas dos ruminantes.

R.O. Leite é a ilustradora das figuras de neuroanatomia deste artigo. A.S. Borges e J.A.N. Lisbôa são bolsistas de produtividade em pesquisa do $\mathrm{CNPq}$.

\section{REFERÊNCIAS}

1. SANCHES, A.W.D. et al. Doenças do sistema nervoso central em bovinos no Sul do Brasil. Pesquisa Veterinária Brasileira,v.20, n.3, p.113-118,2000.

2. BARROS, C.S.L. Neuropatias bovinas emergentes. Ciência Animal Brasileira,v.10, Supl.,p.1-18,2009.

3. KONRADT, G. et al. Suppurative infectious diseases of the central nervous system in domestic ruminants. Pesquisa Veterinária Brasileira, v.37, n.8, p.820$828,2017$.

4. SANTOS, B.L. et al. Doenças do sistema nervoso central de bezerros no sul do Rio Grande do Sul: uma contribuição ao diagnóstico diferencial. Pesquisa Veterinária Brasileira, v.38, n.4,p.685-691,2018.

5. GALIZA, G.J.N. et al. Doenças do sistema nervoso de bovinos no semiárido nordestino. Pesquisa Veteriná- ria Brasileira,v.30, n.3,p.267-276,2010.

6. RIBAS, N.L.S. et al. Doenças do sistema nervoso de bovinos no Mato Grosso do Sul: 1082 casos. Pesquisa Veterinária Brasileira,v.33, n.10, p.1183-1194,2013.

7. OLIVEIRA, T.S. et al. Neurological diseases of cattle diagnosed by histopathology in Minas Gerais. Brazilian Journal of Veterinary Pathology, v.9, n.2, p.62-69, 2016.

8. TERRA, J.P. et al. Neurological diseases of cattle in the state of Goiás, Brazil (2010-2017). Pesquisa Veterinária Brasileira,v.38, n.9, p.1752-1760,2018.

9. QUEIROZ, G.R. et al. Diagnóstico diferencial das doenças neurológicas dos bovinos no estado do Paraná. Pesquisa Veterinária Brasileira, v.38, n.7, p.1264-1277, 2018. 
10. GUEDES, K.M.R. et al. Doenças do sistema nervoso central em caprinos e ovinos no semi-árido. Pesquisa Veterinária Brasileira, v.27, n.1, p.29-38,2007.

11. RISSI, D.R. et al. Doenças neurológicas de ovinos na região Central do Rio Grande do Sul. Pesquisa Veterinária Brasileira v.30, n.3, p.222-228,2010.

12. RISSI, D.R. et al. Abordagem diagnóstica das principais doenças do sistema nervoso de ruminantes e equinos no Brasil. Pesquisa Veterinária Brasileira v.30, n.11,p.958-967,2010.

13. MORIN, D.E. Brainstem and cranial nerve abnormalities: listeriosis, otitis media/interna, and pituritary abscesso syndrome. Veterinary Clinics of North America, Food Animal Practice,v.20,n.2,p.243-273, 2004.

14. SANT'ANA, F.J.F. et al. Polioencefalomalacia em ruminantes. Pesquisa Veterinária Brasileira v.29, n.9, p.681-694,2009.

15. TOKARNIA, C.H. et al. Plantas tóxicas do Brasil. $2^{a}$. ed. Rio de Janeiro: Editora Helianthus. 566p. 2012.

16. RIET-CORREA, F. et al. Toxic plants affecting the nervous system of ruminants and horses in Brazil. Pesquisa Veterinária Brasileira v.37, n.12, p.1357-1368, 2017.

17. QUEIROZ, G.R. et al. Intoxicação espontânea de bovinos por Senna obtusifolia no estado do Paraná. Pesquisa Veterinária Brasileira, v.32, n.12, p.1263-1271, 2012.

18. SALVADOR, S.C. et al. Meningoencefalite em bovinos causada por herpesvírus bovino-5 no Mato Grosso do Sul e São Paulo. Pesquisa Veterinária Brasileira,v.18, n.2, p.75-82, 1998.

19. ELIAS, F. et al. Meningoencefalite e encefalomalacia por Herpesvírus bovino-5: distribuição das lesões no sistema nervoso central de bovinos naturalmente infectados. Pesquisa Veterinária Brasileira, v.24, n.3, p.123-131,2004.

20. RISSI, D.R. et al. Epidemiologia, sinais clínicos e distribuição das lesões encefálicas em bovinos afetados por meningoencefalite por herpesvírus bovino-5. Pesquisa Veterinária Brasileira,v.26, n.2, p.123-132,2006.

21. LUNARDI, M. et al. Neurological and epidemiological aspects of a BoHV-5 meningoencephalitis outbreak. Brazilian Archives of Biology and Technology, v.52, n.spe.,p.77-85,2009.

22. NAKAZATO, L. et al. Polioencefalomalacia em bovinos nos estados de Mato Grosso do Sul e São Paulo. Pesquisa Veterinária Brasileira, v.20, n.3, p.119-125, 2000.

23. MENDES, L.C.N. et al. Estudo retrospectivo de 19 casos de polioencefalomalacia, em bovinos, responsivos ao tratamento com tiamina. Arquivo Brasileiro de Medicina Veterinária e Zootecnia, v.59, n.1, p.239-241, 2007.

24. SANT'ANA, F.J.F. et al. Polioencefalomalácia em bovinos: epidemiologia, sinais clínicos e distribuição das lesões no encéfalo. Pesquisa Veterinária Brasileira, v.29, n.7, p.487-497, 2009.

25. CUNHA, P.H.J. et al. Surto de polioencefalomalacia por ingestão excessiva de enxof re na dieta em bezerros no Rio Grande do Sul. Pesquisa Veterinária Brasileira,v.30, n.8, p.613-617,2010.

26. RODRIGUES, A. et al. Babesiose cerebral em bovinos: 20 casos. Ciência Rural,v.35, n.1,p.121-125, 2005.

27. ANTONIASSI, N.A.B. et al. Surto de babesiose cerebral em bovinos no estado do Rio Grande do Sul. Ciência Rural,v.39, n.3, p.933-936,2009.

28. CÂMARA, A.C.L. et al. Surtos de babesiose cerebral em bovinos leiteiros no nordeste brasileiro. Ciência Animal Brasileira,v.10, supl.1,p.619-624,2009. 
29. MARQUES, L.C. et al. Surto de febre catarral maligna em bovinos no estado de São Paulo. Arquivo Brasileiro de Medicina Veterinária e Zootecnia, v.38, n.4, p.719-729, 1986.

30. LEMOS, R.A.A. et al. Febre catarral maligna em bovinos no Mato Grosso do Sul e de São Paulo. Ciência Rural,v.35,n.40,p.932-934,2005.

31. RECH, R.R. et al. Febre catarral maligna em bovinos no Rio Grande do Sul: epidemiologia, sinais clínicos e patologia. Pesquisa Veterinária Brasileira, v.25, n.2, p.97-105,2005.

32. MACÊDO, J.T.S.A. et al. Febre catarral maligna em bovinos na Paraíba. Pesquisa Veterinária Brasileira, v.27,n.7,p.277-281,2007.

33. MENDONÇA, F.S. et al. Febre catarral maligna em bovinos no estado de Mato Grosso. Pesquisa Veterinária Brasileira,v.28, n.3, p.155-160, 2008.

34. HEADLEY, S.A. et al. Histophilus somni-induced thrombotic meningoencephalitis in cattle from northern Paraná, Brazil. Pesquisa Veterinária Brasileira, v.35, n.4,p.329-336, 2015.

35. QUEIROZ, G.R. et al.Intoxicação espontânea por Crotalaria incana em bovinos no norte do estado do Paraná. Semina Ciências Agrárias, v.34, n.2, p.823-832, 2013.

36. LANGOHR, I.M. et al. Aspectos epidemiológicos, clínicos e distribuição das lesões histológicas no encéfalo de bovinos com raiva. Ciência Rural, v.33, n.1, p.125-131,2003.

37. REIS, M.C. et al. Aspectos clínicos e epidemiológicos da raiva bovina apresentados na casuística da clínica de bovinos (Oliveira dos Campinhos, Santo Amaro, Bahia), Universidade Federal da Bahia, durante o período de janeiro de 1990 a dezembro de 1999. Revista Brasileira de Saúde e Produção Animal, v.4, n.1, p.12-
17,2003.

38. LIMA, E.F. et al. Sinais clínicos, distribuição das lesões no sistema nervoso e epidemiologia da raiva em herbívoros na região nordeste do Brasil. Pesquisa Veterinária Brasileira, v.25, n.4,p.250-264,2005.

39. LISBÔA, J.A.N. et al. Epidemiologia e quadro clínico do botulismo epizoótico dos bovinos no estado de São Paulo. Pesquisa Veterinária Brasileira, v.16, n.2/3, p.67-74, 1996.

40. SCOTT, P.R. Diagnostic techniques and clinicopathologic findings in ruminant neurologic disease. Veterinary Clinics of North America, Food Animal Practice, v.20, n.2,p.215-230, 2004.

41. CÂMARA, A.C.L. et al. Cerebrospinal fluid analysis in 58 ruminants showing neurological disorders. Pesquisa Veterinária Brasileira, v.40, n.5, p.346-354, 2020.

42. QUEIROZ, G.R. et al. Cerebrospinal fluid changes in cattle with rabies or with BoHV-5 meningoencephalitis and its correlation with the severity of CNS inflammatory process. Research in Veterinary Science, v.118, p.389-394,2018.

43. CURTI, J.M. et al. L-lactate in cerebrospinal fluid can be used as a biomarker of encephalitis in cattle. Canadian Journal of Veterinary Research, v.84, n.2, p.146-152,2020.

44. LISBÔA, J.A.N. et al. Hematological and cerebrospinal fluid changes in cattle naturally and experimentally infected with the bovine herpesvírus 5 . Brazilian Archives of Biology and Technology, v.52, n.spe, p.69-76,2009.

45. SMITH, M.O.; GEORGE, L.W. Diseases of the nervous system. In: SMITH, B.P. Large Animal Internal Medicine. $4^{\text {th }}$ ed. St. Louis: Mosby Elsevier. p.9721111,2009. 